Peer-reviewed article forthcoming in the American Journal of Comparative Law. This document is a draft. Its final, updated version will appear in the journal in 2022.

\title{
Death Penalty Abolitionism From the Enlightenment to Modernity
}

\author{
Mugambi Jouet* \\ Assistant Professor \\ McGill Faculty of Law
}

\begin{abstract}
$\underline{\text { Abstract }}$
The modern movement to abolish the death penalty in the United States stresses that this punishment cannot be applied fairly and effectively. The movement does not emphasize that killing prisoners is inhumane per se. Its focus is almost exclusively on administrative, procedural, and utilitarian issues, such as recurrent exonerations of innocents, incorrigible racial discrimination, endemic arbitrariness, lack of deterrent value, and spiraling financial costs. By comparison, modern European law recognizes any execution as an inherent violation of human rights rooted in dignity. This humanistic approach is often assumed to be "European" in nature and foreign to America, where distinct sensibilities lead people to concentrate on practical problems surrounding executions. In reality, this Article demonstrates that the significant transatlantic divergence in abolitionism is a relatively recent development. By the late eighteenth century, abolitionists in Europe and America recurrently denounced the inhumanity of executions in language foreshadowing modern human rights norms. Drawing on sources overlooked by scholars, including the views of past American and French abolitionists, the Article shows that reformers previously converged in employing a polyvalent rhetoric blending humanistic and practical objections to executions. It was not before the 1970s and 1980s that a major divergence materialized. As America faced an increasingly punitive social climate leading to the death penalty's resurgence and the rise of mass incarceration, its abolitionists largely abandoned humanistic claims in favor of practical ones. Meanwhile, the opposite generally occurred as abolitionism triumphed in Europe. These findings call into question the notion that framing the death penalty as a human rights abuse marks recent shifts in Western Europe or international law. While human rights have indeed become the official basis for abolition in modern Europe, past generations of European and U.S. abolitionists defended similar moral and political convictions. These humanistic norms reflect a longterm evolution traceable to the Renaissance and Enlightenment. But for diverse social transformations, America may have kept converging with Europe in gradually adopting humanistic norms of punishment.
\end{abstract}

\footnotetext{
* I am grateful to Glen M. Johnson, Joshua Kleinfeld, Frédéric Mégret, Sherod Thaxton, and Franklin Zimring
} for their helpful suggestions on this project. 


\section{TABLE OF CONTENTS}

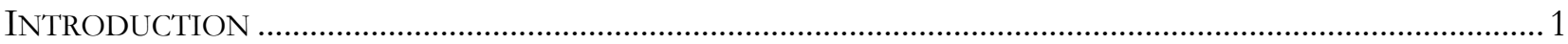

I. Theorizing the Evolution of Capital Punishment AND Human Rights............................. 5

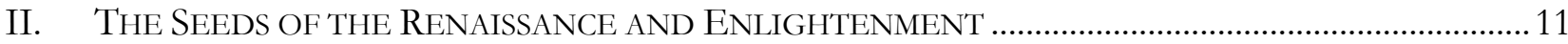

A. Beccaria's Momentous Abolitionist Discourse.................................................................................... 12

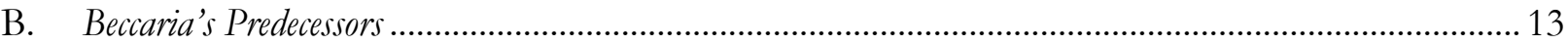

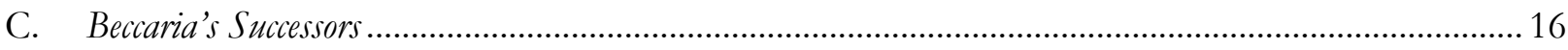

III. FROM THE AMERICAN ENLIGHTENMENT TO FURMAN ………………………………................... 22

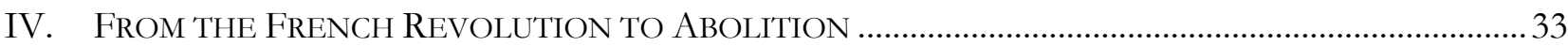

V. The Modern Transatlantic Divergence: “A Human Rights Violation” Versus “A

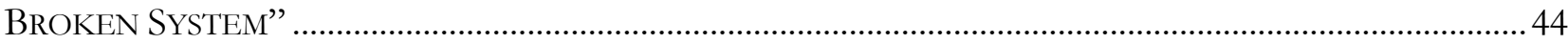

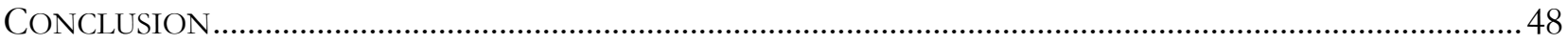




\section{INTRODUCTION}

As America stands increasingly isolated in retaining the death penalty, ${ }^{1}$ two Supreme Court Justices made a clarion call for abolition. In a case upholding lethal injection procedures, Stephen Breyer and Ruth Bader Ginsburg went beyond the pleadings in a dissent encouraging litigators to bring a test case for outright abolition. Their landmark opinion marshaled a host of reasons, including recurrent due process violations, racial discrimination, and exonerations of innocents. ${ }^{2}$ The dissent, republished in a book titled Against the Death Penalty, was essentially an abolitionist manifesto. ${ }^{3}$ What it omitted in its twenty-two pages and five appendices is therefore striking. The dissent nowhere suggests that killing prisoners is cruel or inhumane per se. Rather, it focuses exclusively on administrative, procedural, and utilitarian problems. The landmark Breyer-Ginsburg opinion embodies modern American abolitionism. Its approach reflects the now-popular notion that the death penalty system is irremediably "broken." "It is fundamentally a practical argument_executing people "does not work."

By contrast, European authorities recognize the death penalty as an inherent violation of human rights and human dignity in all cases and under all circumstances. ${ }^{5}$ This humanistic approach denies the relevance of practical problems because killing prisoners is unjustifiable. The prisoner's right to life has become inalienable. ${ }^{6}$

1 AMNESTY INT'L, Abolitionist and Retentionist Countries as of July 2018 (2018), https://www.amnesty.org/download/Documents/ACT5066652017ENGLISH.pdf (last visited Feb. 13, 2020).

${ }^{2}$ Glossip v. Gross, 135 S. Ct. 2726, 2755-80 (2015) (Breyer, J., dissenting). See also Barr v. Lee, No. 20A8, slip. op. at 2 (U.S. July 14, 2020) (per curiam) (Breyer, J., dissenting) (reiterating this position in case concerning the federal death penalty's resumption following a seventeen-year hiatus).

3 Stephen Breyer, Against THe Death Penalty (John Bessler ed., 2016).

${ }^{4}$ See infra note 383 and accompanying text.

5 See, e.g., COUNCIL OF EUROPE \& EUROPEAN UNION, Joint Declaration by the EU High Representative for Foreign Affairs and Security Policy and the Secretary General of the Council of Europe on the European and World Day Against the Death Penalty, 9 Oct. 2018, https://www.consilium.europa.eu/en/press/pressreleases/2018/10/09/joint-declaration-by-the-eu-high-representative-for-foreign-affairs-and-security-policyand-the-secretary-general-of-the-council-of-europe-on-the-european-and-world-day-against-the-deathpenalty/ (last visited Feb. 12, 2020) [hereinafter Joint Declaration on the Death Penalty].

6 See generally Al-Saadoon \& Mufdhi v. United Kingdom, App. No. 61498/08 Eur. Ct. H.R. ๆף 115-23 (2010) (holding that capital punishment inherently violates the European Convention on Human Rights). Regarding this case, see infra note 376 and accompanying text. 
Draft. Final, updated version forthcoming in American Journal of Comparative Law.

The divergence is not absolute, as certain Americans argue that executing prisoners is intrinsically immoral, ${ }^{7}$ despite the U.S. debate's focus on practical concerns. ${ }^{8}$ It may well be that most American abolitionists categorically oppose capital punishment on moral grounds but choose to stress consequentialist objections due to actual or perceived constraints, such as the greater receptiveness of U.S. judges, legislators, and public opinion to problems like innocence and discrimination. ${ }^{9}$ Nevertheless, a significant divergence in framing abolitionism exists in America and Europe nowadays.

The stakes in framing the issue are critical. Although death sentences and executions have dropped in twenty-first century America, amid declining public support, ${ }^{10}$ it remains among the leading executioners worldwide alongside dictatorial regimes. ${ }^{11}$ The profound divergence in framing abolitionism in Europe and America is often assumed to reflect distinct sensibilities. Europeans appear disposed toward humanistic concerns about killing, whereas Americans focus on practical problems because they have fewer moral reservations about executing murderers. Put otherwise, a consequentialist approach is assumed to be a fundamental trait of American culture, whereas European culture embraces deontological arguments about human rights and dignity. This reputation is partly a stereotype and is substantially false in the death penalty context, as European and American abolitionism long had more in common than is generally understood.

This Article documents how the transatlantic divergence is relatively recent. For much of history, abolitionists in Europe and America converged in employing a polyvalent discourse encompassing humanistic and practical objections to capital punishment. Yet humanistic approaches

\footnotetext{
7 See, e.g., Helen Prejean, Dead Man Walking: An Eyewitness Account of the Death Penalty in THE UNITED STATES (1993); BRYAN STEVENSON, JUST MERCY: A STORY OF JUSTICE AND REDEMPTION 290 (2014); Editorial, Every Execution Is Inhumane, L.A. TimES, Mar. 16, 2018, at 12; AM. CIV. LiBERTIES UnION, The Case Against the Death Penalty, https://www.aclu.org/other/case-against-death-penalty (last visited July 22, 2020) ("[T] he state should not give itself the right to kill human beings ...").

8 See Carol S. Steiker \& Jordan M. Steiker, Courting Death: The Supreme Court and Capital PUNISHMENT 248 (2016) (discussing "the failure of a human rights approach to capital punishment" in America); NAt'l Coalition to Abolish the Death Penalty, About the Death Penalty http://www.ncadp.org/pages/about (last visited July 25, 2020) (presenting exclusively practical rationales for abolition).

${ }^{9}$ Carol S. Steiker \& Jordan M. Steiker, No More Tinkering: The American Law Institute and the Death Penalty Provisions of the Model Penal Code, 89 TEX. L. REV. 353, 364-65 (2010) (noting the relative social success of consequentialist objections to capital punishment). See also SARAh Beth Kaufman, American RouletTe: The Social LOGIC OF DEATH PENALTY SENTENCING TRIAls 72 (2020) (describing how elite anti-death-penalty lawyers fundamentally oppose executions but must operate within the field's constraints).

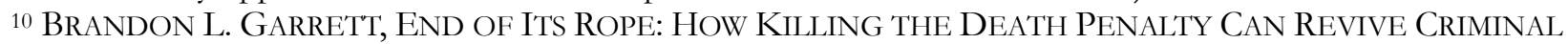
Justice (2017); Death Penalty Info. Ctr., The Death Penalty in 2019 (2019).

11 AMNESTY INT'L, Death Sentences and Executions 2018 4-5 (2019), https://www.amnesty.org/download/Documents/ACT5098702019ENGLISH.PDF (last visited June 27, 2020).
} 
toward criminal justice fell out of favor in America around the 1970s and 1980s. America then not only chose to retain the death penalty when other Western democracies cemented abolition. ${ }^{12}$ America's prison population also exploded, leading to the highest incarceration rate worldwide. ${ }^{13}$ This harsher climate led U.S. abolitionism to focus narrowly on administrative, procedural, and utilitarian objections to executions. In the same period, European authorities increasingly recognized the death penalty as a human rights violation. They consequently refused to facilitate executions in America, such as by barring the extradition of detainees who might face capital punishment. ${ }^{14}$ These circumstances fostered the misconception that humanistic objections to the death penalty are largely foreign to America and fundamentally "European" in nature.

In other words, abolitionism has historically had a humanistic component that is now commonly eclipsed in America. This may reflect diverse dimensions of American exceptionalism, the notion that America has objectively become an "exception" compared to other countries, especially Western democracies, due to singular historical and societal circumstances. ${ }^{15}$ Extensive scholarship has focused on how, starting in the 1970s, the rise of mass incarceration and resurgence of the death penalty in the United States marked the social normalization of extraordinary harshness. ${ }^{16}$ This profound divergence tends to overshadow how America was not always an outlier.

The Article examines sources widely overlooked by criminal justice scholars and comparatists to demonstrate how generations of American abolitionists denounced the death penalty's inhumanity, including influential figures like Benjamin Rush, Ralph Waldo Emerson, Henry David Thoreau, Frederick Douglass, Sojourner Truth, Susan B. Anthony, Lydia Maria Child, Walt Whitman, Clarence Darrow, and Martin Luther King. ${ }^{17}$ The Article further compares the historical evolution of abolitionism in America and France to shed light on processes of convergence and divergence. Buoyed by "sister revolutions" born of Enlightenment ideas, ${ }^{18}$ America and France offer instructive comparisons as nations where reformers began questioning the death penalty in the late eighteenth century. Given rabid use of the guillotine during the French Revolution, it may seem hard to believe

12 See generally David Garland, Peculiar institution: America's Death Penalty in an Age of ABOLITION (2010).

13 WORld PRISON BRIEF, PRISON POPUlation RATE, https://www.prisonstudies.org/highest-tolowest/prison_population_rate?field_region_taxonomy_tid=All (last visited June 27, 2020).

14 See infra Section V.

${ }^{15}$ Mugambi Jouet, Exceptional America: What Divides Americans From the World and From EACH OTHER 20-26 (2017) (discussing the history of "American exceptionalism" as a concept).

16 See generally id. at ch. 7.

17 See infra Section III.

18 See Susan Dunn, Sister Revolutions: French Lightning, American Light (1999). 
that it spurred a fervent abolitionist movement, yet it did. ${ }^{19}$ Drawing on neglected French materials, some translated here for the first time, the Article shows that French abolitionists long held similar views to their American counterparts, as illustrated by Voltaire, Condorcet, Lafayette, Victor Hugo, Albert Camus, and Robert Badinter.

The humanistic rhetoric of past abolitionists, whether in Europe or America, foreshadowed modern conceptions of human rights and dignity. These findings call into question leading theories concluding that human rights are an invention of modernity ${ }^{20}$ or that executions were not considered a human rights issue before a shift in Western Europe in the late twentieth century. ${ }^{21}$ However, these theories shed light on how human rights have intensified in modernity. In particular, Franklin Zimring has insightfully documented the divergence in framing abolition as a human rights issue in Europe, compared to a practical one in America. ${ }^{22}$ This Article's findings suggest that the divergence that Zimring pinpointed is the present point in a longer evolution under which abolitionism largely converged for generations.

We will see that humanistic reservations toward executions emerged in the Renaissance, as the writings of Thomas More, Montaigne, and Erasmus demonstrate. This normative evolution shaped Enlightenment philosophy, including Cesare Beccaria's crucial call to abolish the death penalty in $1764,{ }^{23}$ which inspired reformers on both sides of the Atlantic. ${ }^{24}$ Even though this historical evolution has not been linear, ${ }^{25}$ it partly confirms Émile Durkheim's sociological theory on the long-term expansion of prisoners' rights. ${ }^{26}$ Durkheim hypothesized that punishments gradually milden as societies evolve from absolute monarchies toward liberal democracies. ${ }^{27}$ Growing empathy toward prisoners is tied to an expanding norm of "human dignity," 28 namely the intrinsic worth of human life at an abstract level. ${ }^{29}$ As we will see, Victor Hugo, the French writer and legislator, presented a similar

\footnotetext{
19 See infra Section IV.

20 SAMUEL Moyn, THE LAST Utopia: Human RightS in History (2010).

${ }^{21}$ FrankLin E. Zimring, THE CONTRADiCTIONS OF AMERICAN CAPITAL PUNISHMENT 24-31 (2003).

22 See infra Section I.

${ }^{23}$ Cesare Beccaria, On Crimes and Punishments 48-52 (David Young trans., 1986).

24 See infra Section II.

25 Mugambi Jouet, Mass Incarceration Paradigm Shift?: Convergence in an Age of Divergence, 109 J. CRIM. L. \& CRIMINOLOGY 703, 750-65 (2019).

${ }^{26}$ Émile Durkheim, Deux lois de l'évolution pénale, 4 ANNÉE SOCIOLOGIQUE 65 (1900).

27 Id. at 65, 74-77, 87, 91-95.

${ }^{28} \mathrm{Id}$. at 88.

29 See generally Paul Cassia, Dignité(S) 30-33, 39-51, 55-56 (2016); George KateB, Human Dignity ix (2011); Xavier Bioy, Le concept de dignité, in LA DIGNITÉ SAISIE PAR LES JUGES EN EUROPE 13, 23-34 (Laurence Burgorgue-Larsen ed., 2010).
} 
theory half a century earlier. ${ }^{30}$ After centuries of incremental evolution, including backlashes and regressions, these humanistic norms have become the foundation of abolitionism in Europe. America may have taken the same path but for diverse contingencies, from social shifts toward the end of the twentieth century to the Supreme Court's refusal to categorically abolish capital punishment under evolving standards of decency. ${ }^{31}$

\section{THEORIZING THE Evolution OF CAPITAL PUNISHMENT AND HuMAN RIGHTS}

This section situates the Article's thesis in contrast to leading theories on the history of the death penalty and human rights. We will notably explore how a glaring modern divergence has obscured a past convergence.

Our starting point is a pivotal book by Franklin Zimring, The Contradictions of American Capital Punishment (2003), which examined abolitionism on opposite sides of the Atlantic. Zimring's magnum opus stood out by offering insight into both American and European law. While European abolitionists frame it as a human rights violation, their American counterparts focus on its inutility and unfair implementation. ${ }^{32}$ Zimring argues that this divergence reflects a recent paradigm shift in Western Europe, which did not conceive capital punishment as a human rights issue before the end of the twentieth century. ${ }^{33}$ Until then, it was merely a matter of penal policy rather than a "moral" or "political" question regarding "the proper limits of government power." 34 According to Zimring, it was only after European countries achieved abolition at the domestic level that they reframed the death penalty as a human rights issue around the 1970s and 1980s under the aegis of the Council of Europe- the most influential international body on the continent alongside the European Union. ${ }^{35}$

\footnotetext{
30 Victor Hugo, Loi sur les prisons (Speech at National Assembly, May 4, 1847), in CEUVRES POLITIQUES COMPLÈTES - CEUVRES DIVERSES 143, 143-44 (Jean-Jacques Pauvert ed., 1964). See infra note 292 and accompanying text.

31 STEIKER \& STEIKER, COURTING DEATH, supra note 8, at 74-77.

32 See, e.g., ZIMRING, supra note 21, at 46-47 (contrasting claims of Amnesty International branches in America and Europe).

${ }^{33} \mathrm{Id}$. at $25-27,30-32,40-41$.

${ }^{34}$ Id. at 17, 25 (quote), 27, 29, 49.

35 See generally id. at 25, 32, 40. See also Andrew Hammel, Ending the Death Penalty: The European EXPERIENCE IN GLOBAL PERSPECTIVE 10, 14, 202, 206 (2010) (arguing that capital punishment in America and Europe diverged from the 1960s to 1980s, following centuries of convergence).
} 
Zimring emphasizes that abolitionism was generally not a reaction to the atrocities of World War Two, as Allied victors executed war criminals. ${ }^{36}$ Nor was it part of the international human rights movement born in the war's immediate aftermath. Zimring instead identifies a shift with Protocol No. 6 of the European Convention on Human Rights. This 1983 treaty provided for the death penalty's abolition except in wartime. ${ }^{37}$ The reframing of abolition as an international human rights issue entailed a universalist mission under which the Council and individual European states came to support abolition throughout the continent and worldwide. ${ }^{38}$ They consequently refused to cooperate with foreign countries seeking to apply the death penalty, including the United States, such as by denying extraditions or requests for evidence. ${ }^{39}$ International human rights groups likewise played a role in this transformation, especially Amnesty International. ${ }^{40}$ By contrast, whether the death penalty violates human rights "is almost never debated in the United States."

In sum, Zimring theorizes that a normative shift occurred relatively recently in the 1970 s and 1980s in Western Europe. ${ }^{42}$ Despite recognizing that the Enlightenment philosopher Cesare Beccaria presented in 1764 "the first detailed and influential" call for abolition, ${ }^{43}$ Zimring argues that the claims of Beccaria and other pre-modern abolitionists were distinct in nature from modern human rights claims. Stressing that "the European focus on the political nature of capital punishment has a very short history," ${ }^{4}$ Zimring underlines the implications of his theory: "[O]ne can be astonished that the political and human rights dimensions of the death penalty were repressed for so very long even by those who were seeking to stop executions." ${ }^{45}$

Another leading theory is relevant to our thesis. Samuel Moyn has argued that the human rights movement suddenly emerged in the 1970 s and had practically no antecedents. ${ }^{46}$ He denies that it was a reaction to the Holocaust and other atrocities of World War Two, as "no international rights

36 ZIMRING, supra note 21, at 19-20, 30-31, 33.

37 Id. at $29-31$.

38 Id. at $17,25-37$.

${ }^{39} I d$. at $42-45,183$.

$40 \mathrm{Id}$. at 28 .

41 Id. at 46.

${ }^{42}$ For instance, Zimring refers to "the failure to engage state execution as a human rights problem in the $1950 \mathrm{~s}$ and 1960s in places such as Britain and France," $i d$. at 32, "[t] he rhetorical transformation in Europe that started in the late 1970s," "[t] he broader concerns that emerged in the 1980s," $i d$. at 40.

${ }^{43} \mathrm{Id}$. at 17 (quote), 25, 34.

44 Id. at 49.

45 Id. at 25.

46 MOYN, supra note 20, at 1-3, 118-19, 120-21, 129, 215-16. 
movement emerged at the time." ${ }^{47}$ This is hard to reconcile with the adoption in 1948 of the Universal Declaration of Human Rights and the Convention on Genocide. Moyn equally dismisses the idea that human rights have earlier roots in Enlightenment philosophy. ${ }^{48} \mathrm{He}$ disputes that the American Revolution and French Revolution sowed the seeds of modern human rights, as he finds that their declarations of rights were narrowly circumscribed to the nation-state. ${ }^{49}$ To Moyn, the modern human rights movement instead aims to transcend the nation-state with binding international law. Moyn thus refers to the "startling breakthrough" 50 or "true breakthrough" 51 of human rights in the 1970s, with the "breakthrough year" being 1977 when Amnesty won the Nobel Peace Prize. ${ }^{52}$ His theory of recently and suddenly born human rights has proved controversial. ${ }^{53}$

Even though Moyn does not discuss the death penalty or criminal justice, his theory is relevant to the history of abolitionism. If human rights as a whole did not emerge before the 1970s, capital punishment could not have been a human rights issue beforehand. In this regard, a synergy exists between Moyn's theory and Zimring's theory about a recent paradigm shift on capital punishment in Europe.

This Article presents the distinct hypothesis that the death penalty's framing as a human rights issue did not suddenly emerge in Europe in the twentieth century's final decades. Rather, for much of history, abolitionists in both Europe and America recurrently depicted executions as the equivalent of human rights abuses. But that is not all. Abolitionists simultaneously stressed administrative, procedural, and utilitarian objections. That is because abolitionists generally employed a polyvalent discourse. Their objections sometimes encompassed moral claims akin to modern human rights arguments, sometimes practical concerns with how the penalty was applied, and oftentimes both.

How could this be? After all, a tension exists between these two framings. If the death penalty is a human rights violation, problems with its implementation become irrelevant. Because human rights are inalienable, it must then be abolished. As Zimring observes, "the debate begins and ends"

${ }^{47} \mathrm{Id}$. at 7 (quote), 47, 82.

${ }^{48} I d$. at $7,13-14,21-23$.

${ }^{49} \mathrm{Id}$. at $12,23-29$.

${ }^{50} I d$. at 214.

51 Id. at 47.

52 Id. at $118,129,155$

53 See, e.g., Justine Lacroix \& JeAn-Yves Pranchère, Human Rights on Trial 3, 5, 9, 14-18, 20,246 (Gabrielle Maas trans., 2018); Philip Alston, Does the Past Matter? On the Origins of Human Rights, 126 HARV. L. REV. 2043, 2049, 2051, 2065-70 (2013) (reviewing JENNy S. MARTINEZ, THE SLAVE TRADE AND THE Origins Of International Human Rights LaW (2012)); Jenny S. Martinez, Human Rights and History, 126 Harv. L. REV. F. 221, 232-40 (2013). 
with this premise about human rights. ${ }^{54}$ Because this premise lacks weight in America, including in abolitionist rhetoric, the U.S. debate instead centers on administrative, procedural, and utilitarian matters. ${ }^{55}$

Yet the tension between these two framings is greater nowadays than in the past. That may be because human rights norms have strengthened in Europe since approximately the 1970s, the breakthrough period that both Moyn and Zimring thoughtfully describe. This enabled European abolitionists to place less weight on practical objections. But this does not signify that human rights claims were essentially absent in the past. They instead carried less weight. In societies where humanistic norms are less established, abolitionists are likely to pair human rights claims with practical objections to capital punishment as part of a polyvalent rhetoric. Once a society is prepared to fully approach the death penalty as a human rights issue, however, abolitionists may solely focus on human rights claims. Until that point, social circumstances and strategic considerations may disincentivize abolitionists from overrelying on humanistic rhetoric.

This Article suggests that the transatlantic divergence that Zimring documented is the present point of a long-term historical process. Past generations of abolitionists in America and Europe tended to converge toward a polyvalent rhetoric encompassing humanistic and practical objections to capital punishment. ${ }^{56}$ Around the 1970 s, shifts on each side of the Atlantic led to the divergence at the heart of Zimring's theory. ${ }^{57}$ Humanistic claims declined in America, where abolitionism increasingly focused on the unfair application and ineffectiveness of capital punishment. ${ }^{58}$ This was partly a path dependence resulting from the Supreme Court's landmark decisions in Furman v. Georgia (1972) and Gregg v. Georgia (1976), where most Justices refused to frame the death penalty's constitutionality as a human rights or normative question, instead focusing on administrative, procedural, and utilitarian issues. While Furman technically abolished the death penalty in a divisive 5-4 vote, Gregg swiftly reinstituted it in a 7-2 decision four years later. ${ }^{59}$ Coupled with retribution's resurgence as a respectable value in America, ${ }^{60}$ these circumstances helped shape a form of abolitionism that avoids humanistic

\footnotetext{
54 ZIMRING, supra note 21, at 46.

${ }^{55}$ Id. at 46-48. Accord Steiker \& Steiker, No More Tinkering, supra note 9, at 364-65.

56 See infra Sections II, III, and IV.

57 See infra Section V.

${ }^{58}$ Carol S. Steiker \& Jordan M. Steiker, Cost and Capital Punishment: A New Consideration Transforms an Old Debate, 2010 U. CHI. LEGAL F. 117, 151-55 (2010).

${ }^{59}$ Gregg v. Georgia, 428 U.S. 153 (1976) (plurality opinion); Furman v. Georgia, 408 U.S. 238 (1972) (per curiam). 60 Stuart Banner, The Death Penalty: An American History 282 (2002); Steiker \& Steiker, COURTING DEATH, supra note 8, at 71-77.
} 
principles and narrowly centers on practical problems: discrimination, innocence, cost, lack of deterrence, etc. Conversely, humanistic claims enjoyed a breakthrough in Europe in the 1970s and 1980s, where they supplanted practical objections to capital punishment. ${ }^{61}$ Figure 1 conceptualizes this process of convergence and divergence.

\section{Figure 1: Historical Convergence and Divergence of Abolitionist Discourse}

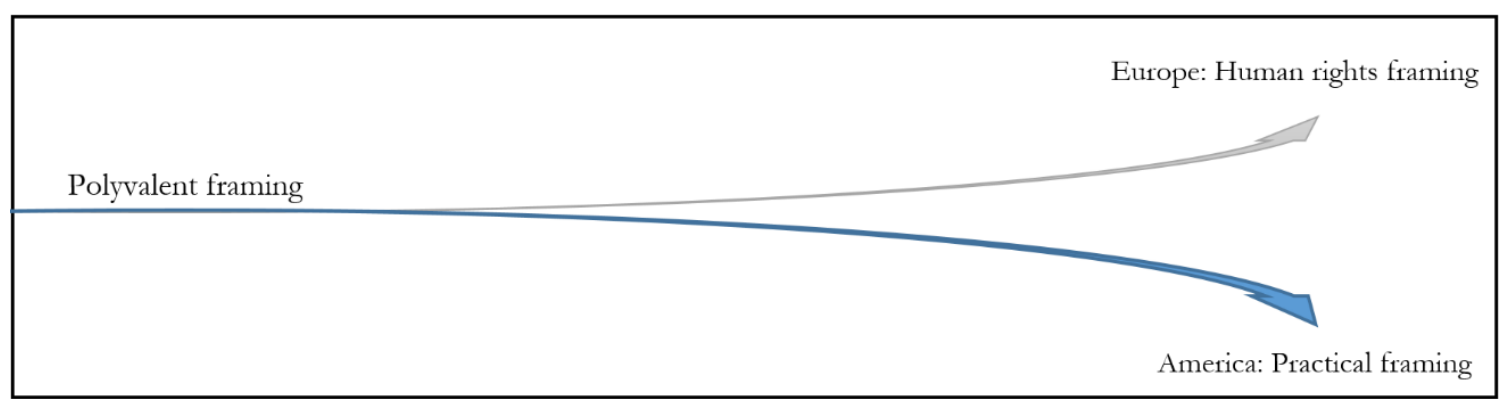

Human rights abolitionist claims are not the fruit of a relatively recent paradigm shift in Europe. One can find their roots in the Enlightenment, if not earlier in the Renaissance. Besides Europe they also came to play a significant role in the United States once it became the first modern democracy to emerge from the Enlightenment. That is because erstwhile claims about the death penalty's immorality are analogous, at times identical, to the modern human rights position, which I define as the idea that killing prisoners is fundamentally wrong and inhumane. ${ }^{62}$ Since the eighteenth century American and European abolitionists have frequently argued that executions are cruel, callous, barbarous, degrading or otherwise inhumane. ${ }^{63}$ Their convictions are analogous to the modern position of the Council of Europe and European Union: "The death penalty is an affront to human dignity. It constitutes cruel, inhuman and degrading treatment and is contrary to the right to life. The death penalty has no established deterrent effect and it makes judicial errors irreversible." ${ }^{64}$

The last quoted sentence is likewise relevant in showing that it is possible to stake a staunch human rights position — and add a line about how the death penalty is ineffective and error-prone. Even in the age of human rights, European authorities employ a fairly polyvalent discourse. Still,

${ }^{61}$ See infra Section V.

${ }^{62}$ Human rights can have other components, which Zimring persuasively identifies, such as universalistic aspirations that led to European campaigns for global abolition. ZIMRING, supra note 21, at 26-41. Yet abolitionists can believe that executions violate human rights in their country without pursuing an international campaign.

63 See infra Sections II, III, and IV.

${ }^{64}$ Council of Europe \& European Union, Joint Declaration on the Death Penalty, supra note 5. 
European abolitionism has strongly gravitated toward a humanistic rationale. ${ }^{65}$ However, the growing weight of human rights does not mean that they had no influence or did not exist in the past.

In particular, Moyn's theory that human rights are a modern invention is partly rooted in the conflation of "human rights" with "international human rights." It leads him to conclude that human rights did not exist before breakthroughs in international law in the 1970s. ${ }^{66}$ This disregards how human rights can emerge in either the national or international sphere. Moyn further discounts how a symbiotic relationship exists between each sphere, as capital punishment's abolition in Europe demonstrates. Abolition started at the national level in a few jurisdictions in the eighteenth and nineteenth centuries, namely Tuscany (1786), ${ }^{67}$ San Marino (1848), Portugal (1867), and the Netherlands (1870). ${ }^{68}$ Abolition gradually expanded throughout the twentieth century, as illustrated by West Germany (1949), the United Kingdom (1965), and France (1981). ${ }^{69}$ This ultimately favored the adoption of the Council of Europe's abolitionist treaties in 1983 and $2002 .^{70}$ Both of these national and international developments favored abolition in remaining countries on the continent, especially former Soviet bloc states, as Zimring shows. ${ }^{71}$ Abolition in international law therefore mostly stems from earlier shifts in national law. ${ }^{72}$

Zimring has invited scholars to further explore the intriguing historic evolution in framing abolitionism, especially whether human rights "were important motivations beneath the surface of death penalty debates long before they emerged in the aftermath of abolition" in Europe. ${ }^{73}$ That is indeed a dimension of our thesis, which further suggests that abolitionism largely converged in America and Europe until approximately the 1970s, when the divergence that Zimring describes materialized. We will see how it is the present point of a long-term historical process.

\footnotetext{
65 See infra Section V.

66 See LACROIX \& PRANCHÈRE, supra note 53, at 246 (Moyn's "staunch rejection of essentialised ideas paradoxically leads him to essentialise human rights in relation to their original context - that of nation-state construction"). Accord Alston, supra note 53, at 2069.

${ }^{67}$ JeAN-YVES LE NAOUR, Histoire DE L'ABOLITION DE LA PEINE DE MORT 42-43 (2011).

${ }_{68}$ These dates concern abolition for ordinary, non-war crimes. AMNESTY INT’L, supra note 1.

69 See id.; LE NAOUR, supra note 67, at 285, 351.

70 See infra notes 367 and 368.

${ }^{71}$ ZIMRING, supra note 21, at 35-37.

72 See LACROIX \& PRANCHÈrE, supra note 53, at 20 ( "Moyn's concern with avoiding anachronism . . leads him to dismiss out of hand lineages of ideas that are not merely semantic"); Martinez, supra note 53, at 237 ("I]deas do not come out of nowhere. ... It would not have been possible for human rights to emerge as a global discourse in the 1970s if the language, ideas, laws, and organizing tools that served as the building blocks of the movement had not already been in existence in some form.").

${ }^{73}$ ZIMRING, supra note 21, at 41.
} 


\section{THE SEEDS OF THE RENAISSANCE AND ENLIGHTENMENT}

This section will describe the gradual emergence of abolitionism in the Renaissance and Enlightenment. In these epochs one can find roots of the modern human rights discourse that capital punishment is immoral and of the practical discourse that it is ineffective or unfairly implemented. Today, the former position has become the ground for abolition in Europe, whereas the latter characterizes American abolitionism. This divergence is largely a modern development. The views of thinkers of the Renaissance and Enlightenment demonstrate that past reformers recurrently denounced both moral and practical problems with the death penalty.

While Beccaria is arguably the first prominent abolitionist, this section will document how earlier thinkers who did not call for outright abolition (e.g., Thomas More, Erasmus, Montaigne, Montesquieu, etc.) helped shape abolitionism. Indeed, pre-Beccaria thinkers expressed moral concerns about the cruelty of executions and sought to limit them to a narrower category of crimes. This ultimately paved the way for full abolition on human rights grounds in Europe-the fruit of a longterm historical process encompassing "a reduced range of capital offenses and eligible offenders," a "decline in the frequency of executions," and "the appearance of sharp divisions in public attitudes towards the penalty's propriety." 74 The gradual elimination of the death penalty is part of a wider evolution that began with the denunciation, limitation, and abolition of torture, mutilation, and other corporal punishments. ${ }^{75}$ Durkheim suggested that as societies evolve away from absolute monarchy toward liberal democracy, ruthless punishments would become acts of "lese humanity," a reformulation of lese majesty. ${ }^{76}$ His theory regarding the gradual mildening of punishments helps us conceptualize this long-term evolution. ${ }^{77}$

In sum, as early as the Renaissance, philosophers began drawing closer to the idea that human worth is inalienable and cannot be forfeited by committing a crime. ${ }^{78}$ This shaped a critical reconsideration of diverse practices, from torture to executions, which intensified during the Enlightenment and kept evolving over time. While this fundamental idea played a meaningful role in

\footnotetext{
${ }^{74}$ David Garland, Capital Punishment and American Culture, 7 PUNISHMENT \& SOC’Y 347, 355 (2005).

75 LE NAOUR, supra note 67, at 16, 18-22, 138.

76 Durkheim, supra note 26, at 89 (my translation).

77 See supra note 26 and accompanying text.

78 See Joshua Kleinfeld, Two Cultures of Punishment, 68 STAN. L. REV. 933, 942, 984-96 (2016).
} 
parts of American history, it culminated with human rights standards fully abolishing the death penalty in modern Europe. This is the connecting thread tying the historical evidence in the Article.

\section{A. Beccaria's Momentous Abolitionist Discourse}

The Enlightenment engendered a reformative spirit in criminal justice. Cesare Beccaria, a Milanese philosopher, was the main catalyst for this paradigm shift. His masterpiece, On Crimes and Punishment (1764), was the first influential call to abolish the death penalty. Its argumentation was polyvalent, conciliating humanistic and utilitarian rationales. Depicting the death penalty as state murder, "a public assassination," 79 he indignantly asked: "By what alleged right can men slaughter their fellows?"80 Beccaria intertwined these normative objections with practical concerns: "Capital punishment is not useful because of the example of cruelty it gives to men." ${ }^{81}$ He equally stressed its lack of deterrent value and discrimination against the indigent. "Who made these laws? Rich and powerful men who have never deigned visit the squalid huts of the poor . . . let us attack injustice at its source," Beccaria proclaimed. ${ }^{83}$ The following statement encapsulates his polyvalent discourse: "If I can demonstrate that capital punishment is neither useful nor necessary . . . I shall have vindicated the cause of humanity." ${ }^{, 84}$

Beccaria planted seeds of the abolitionist discourse existing on each flank of the Atlantic today. His practical objections about the inutility and inequity of capital punishment have become a staple of American abolitionism. His denunciation of its inhumanity is at the root of the human rights rationale prevailing in modern Europe.

Beccaria was not a full abolitionist, as he supported executions for treason posing a risk of security to the state. ${ }^{85}$ His views may appear callous by modern standards insofar as his proposed alternative to death was lifelong forced labor. ${ }^{86}$ Nevertheless, he favored milder and more humane sentences overall. ${ }^{87}$

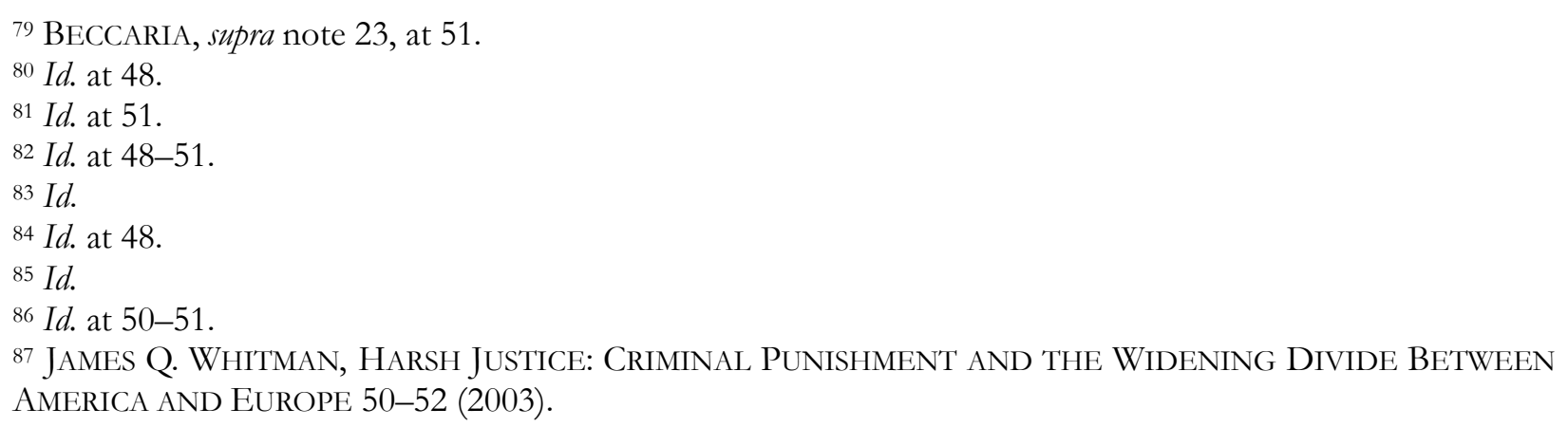


Yet a normative evolution was already underway before On Crimes and Punishment. Although Beccaria (1738-94) is justly recognized as the trailblazer of modern criminal justice, his ideas did not arise ex nibilo, as his reliance on Montesquieu (1689-1755) demonstrates. Beccaria was keen on "follow[ing] the shining footsteps of this great man." 88 In fact, the emergence of humanistic sensibilities toward punishment was already palpable in the views of diverse philosophers of the Renaissance two centuries before Montesquieu.

\section{B. Beccaria's Predecessors}

We begin our overview of this historic evolution with Thomas More (1478-1535), the English statesman and thinker, in light of his substantive arguments and rhetorical approach. In his Utopia (1516), More depicted a fictional world where capital punishment was largely phased out for heinous crimes, and replaced with forced labor offering hope for rehabilitation. ${ }^{89}$

A key passage of More's tale portrays an obtuse royal counsellor astonished that thieves proliferate in Britain despite being routinely executed. A traveler who returned from an imaginary utopia rebukes him: " $[\mathrm{N}]$ o need to wonder: this way of punishing thieves goes beyond the call of justice, and is not in any case for the public good. The penalty is too harsh in itself [and] isn't an effective deterrent.. ${ }^{, 90}$ Although Utopia is at times ambiguous, ${ }^{91}$ this passage suggests that a fair society should address root causes of crime, such as poverty, rather than inflict harsh punishments. ${ }^{92}$ Crime is a symptom of wider ills. This focus on social and institutional mechanisms fostering crime, as opposed to essentialism about human nature or evildoers, was innovative in More's epoch. ${ }^{93}$ It

\footnotetext{
88 BECCARIA, supra note 23 , at 6.

89 Thomas More, UtOPia 85 (Robert M. Adams trans. \& George M. Logan ed., Cambridge U. Press. 3d ed. 2016).

${ }^{90} \mathrm{Id}$. at 15. See also id. at 21-22 (discussing capital punishment for theft and murder); LE NAOUR, supra note 67, at 20 (mentioning Utopia in context of death penalty history).

${ }^{91}$ This interpretive difficulty partly stems from More's use of distinct voices and an occasionally satirical, humorous style. See George M. Logan, The Meaning of More's Utopla 3-18, 114-22, 130 (2014); George M. Logan, The Argument of Utopia, in INTERPRETING THOMAS MORE's UTOPLA 7, 7-8 (John C. Olin ed., 1989); Wolfgang E. H. Rudat, Thomas More and Hythloday: Some Speculations on Utopia, 43 BiBLIOTHÈQUE D’HUMANISME ET RENAISSANCE 123, 124 (1981).

${ }^{92}$ Logan, The Argument of Utopia, supra note 91, at 10-13. But see Susan Bruce, Introduction, in THrEE EARLY MODERN UTOPIAS ix, xxii-xxiv, xxvi (Susan Bruce ed., 2009) (noting ambiguities in Utopia's discussion of capital punishment, as the text features contradictions and satirical elements).

${ }^{93}$ Logan, The Meaning OF MORE's UTOPIA, supra note 91, at 56-60. Cf. Peter Gordon Stillman, Justice, Crime, and Punishment in More's Utopia, in EN UTOPÍA: 500 AÑOs 367, 369-71 (Pablo Guerra ed., 2016) (discussing the "sociological" dimensions of Utopia's treatment of crime).
} 
ultimately evolved into a premise of modern human rights norms: people who commit heinous crimes are not inherently evil and should not face punishments denying their humanity. Naturally, one should be wary of anachronisms. As with other historical figures, a modern reader would be quick to find More's outlook antiquated and rife with contradictions, such as his participation in the burning of heretics. ${ }^{94}$ More would himself succumb to the death penalty-Henry VIII had him beheaded for insubordination. Nevertheless, Utopia remains a significant text in the history of Western civilization.

Utopia demonstrates that polyvalent rhetoric urging the abolition or limitation of capital punishment has distant roots. As a Renaissance humanist, Thomas More was trained in classical rhetoric encompassing the bonestas and utilitas principles, namely honor and utility. Rhetoricians commonly argued that a particular course of action would be either dishonorable or ineffective. Their strongest position would lie in establishing both. ${ }^{95}$ To More, "honor and expediency point in the same direction. . . . The English policy for dealing with theft is both immoral and self-defeating." ${ }^{\text {" }}$ "This helps us understand why skillful rhetoricians in the Renaissance and Enlightenment would not merely contend that the death penalty was inhumane or ineffective in a particular case or in general. They would argue both polyvalently.

The perspective of another leading voice of the Renaissance demonstrates the emergence of humanistic sensibilities foreshadowing modern human rights claims against capital punishment. Montaigne (1533-92) expressed his revulsion toward executions as a magistrate: "[W] hen occasions have summoned me to sentencing criminals, I have tended to fall short of justice. ... horror of the first murder makes me fear a second, and hatred of the first cruelty makes me hate any imitation of it." M7 Montaigne drew on Antiquity to offer ethos to his humane vision of justice: "They say that Aristotle was reproached for having been too merciful to a wicked man. 'In truth,' he said, 'I was merciful to the man, not to the wickedness." ${ }^{98}$ Montaigne pinpointed a conception of justice that has become prevalent in modernity: the distinction between the crime and the criminal or, better yet, the crime and the individual, who should not be essentialized as a "criminal." The notion that a person

\footnotetext{
${ }^{94}$ Bruce, supra note 92, at xxv. According to a leading biography, More deemed heretics "enemies of God, servants of Satan" who "should be exterminated." RICHARD MARIUS, THOMAS MORE: A BIOGRAPHY 406

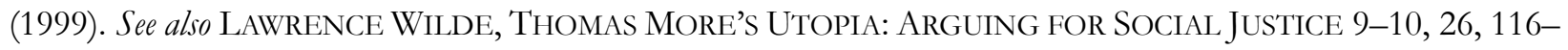
17 (2016) (acknowledging More's participation in and support for the execution of heretics, yet contesting the veracity of certain allegations of persecution).

${ }^{95}$ LOGAN, THE MEANING OF MORE’S UTOPLA, supra note 91, at 13-14, 17-18, 20.

${ }^{96} \mathrm{Id}$. at 15.

${ }^{97}$ Montaigne, The Complete Essays 992 (Donald M. Frame trans., 1965).

${ }^{98}$ Id. Michel de L'Hospital (ca. 1507-73), a contemporary of Montaigne likewise expressed moral reservations about capital punishment's wide scope. LE NAOUR, supra note 67, at 21.
} 
should not be reduced to their worse act is omnipresent in modern human rights, bolstering the norm that punishment should never degrade the offender whose dignity is inalienable. ${ }^{99}$

Elsewhere in his Essays, Montaigne adopts a more utilitarian approach suggesting that incapacitation and deterrence justify the death penalty: "[Offenders] are condemned so that they may not do the same wrong again, or so that others may avoid the example of their wrongdoing." 100 His moral sensibilities nonetheless leaned toward mercy. He thus found corporal punishments inhumane: “[E]ven in justice, all that goes beyond plain death seems to me pure cruelty. . .."101 Montaigne's words troubled Roman censors—-defenders of the status quo-who flagged this passage of the Essays. ${ }^{102}$ Another section of the Essays calls for limiting the scope of capital punishment, such as replacing it with public shaming for dishonorable offenses like desertion. ${ }^{103}$ In passing, Montaigne then referred to freedom of conscience and "the opinion of those who condemn capital punishment for heretics and unbelievers." 104 That line may be interpreted as merely restating others' views without endorsement, perhaps for self-protection. Roman censors flagged this veiled suggestion, too. ${ }^{105}$

Ultimately, Montaigne embodies the emerging paradigm shift toward more humanistic sensibilities under the Renaissance. He proclaimed "I sympathize very tenderly with the afflictions of others"106 and "I cruelly hate cruelty, both by nature and by judgment, as the extreme of all vices." 107 Montaigne tellingly added: "Even the executions of the law, however reasonable they may be, I cannot witness with a steady gaze." 108

Erasmus (ca. 1469-1536), perhaps the most influential figure of the Renaissance, similarly expressed sensibilities suggesting that a normative evolution was underway before the Enlightenment. While he did not go as far as Montaigne, the Dutch philosopher expressed reticence toward executions, even as he recognized their necessity for deterrence and incapacitation. "To persuade men

\footnotetext{
99 See, e.g., Al-Saadoon, Eur. Ct. H.R., supra note 6, 1122 (because the prohibition on "inhuman or degrading treatment or punishment is absolute ... the nature of any offence allegedly committed by the [prisoner] is therefore irrelevant").

100 Montaigne, supra note 97, at 854. See also Jordi Bayod, Montaigne et la peine de mort: Entre la compassion et la prudence, 62 CORPUS: REVUE DE PHILOSOPHIE 305, 311-13 (2012) (discussing utilitarian facets of Montaigne's views).

101 MONTAigne, supra note 97, at 381.

102 Bayod, supra note 100, at 314 .

103 MONTAigne, supra note 97, at 57-59.

${ }^{104} \mathrm{Id}$. at 58.

105 Bayod, supra note 100, at 307-10.

106 MONTAigne, supra note 97, at 380.

107 Id. at 379.

${ }^{108} I d$. at 381. See also id. at 382-83 (describing public executions).
} 
not to break the law, you must first use reasoned arguments, then, as a deterrent, the fear of divine vengeance against criminals, and in addition threats of punishment," he observed in The Education of a Christian Prince (1516). "If these are ineffective, you must resort to punishment, but of a comparatively light kind, more to cure the disease than to kill the patient." ${ }^{109}$ Should this fail, Erasmus endorsed the death penalty to preserve social order, likening the criminal to "a limb" that must be "cut" from the body to protect its health. Despite this gruesome analogy, Erasmus insisted that rulers should do so "reluctantly" and "try all other remedies before resorting to capital punishment." 110 The man known as "the Prince of the Humanists" was urging relatively limited use of the death penalty based on both humanistic and practical concerns two centuries prior Beccaria.

\section{Beccaria's Successors}

Reformers struggled against the status quo, as the death penalty tended to be socially accepted throughout the Renaissance and Enlightenment. ${ }^{111}$ In the landmark Encyclopédie by Diderot and D'Alembert, a vast repository of mid-eighteenth century knowledge, one finds the following passage: "It is doubtless that real sorcerers deserve death, and that even those who are only so by imagination must not be regarded as innocent...." The passage adds that it would be preferable to leave sorcerers unpunished, lest one admit their supernatural powers and reinforce superstition. Society should instead treat them as "madmen." 112 More prosaically, the entry on "criminal law" states that "the law of death against an assassin is very just" because it fosters public safety, although it would usually be excessive for theft. ${ }^{113}$ Another entry posits that corporal punishments or torture may be legitimate because "there are a large number of cases where hope for reform [of the culprit] is lacking, and where

${ }^{109}$ Erasmus, The Education of a Christian Prince 82 (Neil M. Cheshire \& Michael J. Heath trans., Lisa Jardine ed., 1997).

${ }_{110} I d$.

111 See generally LE NAOUR, supra note 67, at 20-24, 33-35.

112 Sorciers et sorcières (Histoire ancienne - Histoire moderne), in ENCYCLOPÉDIE, OU DICTIONNAIRE RAISONNÉ DES SCIENCES, DES ARTS ET DES MÉTIERS, vol. XV (Denis Diderot \& Jean le Rond D’Alembert eds., 1765), http://enccre.academie-sciences.fr/encyclopedie/article/v15-1166-0/ (italics omitted) (my translation).

113 Chevalier Louis de Jaucourt, Loi criminelle, in ENCYCLOPÉDIE, OU DICTIONNAIRE RAISONNÉ DES SCIENCES, DES ARTS ET DES MÉTIERS, vol. IX (Denis Diderot \& Jean le Rond D'Alembert eds., 1765), http://enccre.academie-sciences.fr/encyclopedie/article/v9-1848-56/ (italics omitted) (my translation). Accord Chevalier Louis de Jaucourt, Peine, in ENCYCLOPÉDIE, OU DICTIONNAIRE RAISONNÉ DES SCIENCES, DES ARTS ET DES MÉTIERS, vol. XII (Denis Diderot \& Jean le Rond D’Alembert eds., 1765), http://enccre.academiesciences.fr/encyclopedie/article/v12-486-1/. 
the sentence could be extended until the final torment." 114 Yet the Encyclopédie had diverse contributors and lacked a uniform position on criminal punishment, ${ }^{115}$ as illustrated by entries stating that " $[\mathrm{t}]$ he best jurisconsults have even regarded lex talionis as a barbaric law, contrary to natural law"116 or that corporal punishments are "barbarous" and "cruel." 117 For our purposes, the Encyclopédie assumes the justification of some executions, which is revealing since it represented the views of leading thinkers.

The growing tide against capital punishment is more palpable in the Supplement to the Encyclopédie published in 1776 under Jean-Baptiste Robinet's stewardship. ${ }^{118}$ In the "assassination" entry, an anonymous author describes the use of capital punishment in diverse societies, before seeking another way as "a friend of humanity." Other societies have preferred to banish, ostracize, dispossess or fine murderers while "respecting their lives," the author observes approvingly, adding that they feared offending God by killing wrongdoers. ${ }^{119}$ Besides contending that the death penalty is inhumane vengeance, the Supplement foreshadows the right to life in modern human rights law. ${ }^{120}$ Indeed, the anonymous philosopher disputes that a murderer forfeits "all rights he may have on his own life." This humanistic claim is supplemented by a utilitarian one: even if the murderer could forfeit this right to life, "it would still remain to be seen whether the interest of society would be served" by executing him. ${ }^{121}$

Insofar as the Supplement espoused abolition and distanced itself from the initial Encyclopédie, the anonymity of its "assassination" entry is intriguing. But it does not permit us to conclude that its author was Diderot, the most prominent philosopher associated with the Encyclopédie, despite speculation to this effect. ${ }^{122}$ Although Beccaria's On Crimes and Punishment enthused Diderot, just as

114 Châtiment, in ENCYCLOPÉDIE, OU DICTIONNAIRE RAISONNÉ DES SCIENCES, DES ARTS ET DES MÉTIERS, vol. III (Denis Diderot \& Jean le Rond D'Alembert eds., 1753), http://enccre.academiesciences.fr/encyclopedie/article/v3-406-0/ (my translation).

115 Luigi Delia, La peine de mort dans L'Encyclopédie et ses Suppléments, 35 REVUE FRANÇAISE D'HISTOIRE DES IDÉES POLITIQUES 93, 98-100 (2012).

116 Loi du talion, in ENCYCLOPÉDIE, OU DICTIONNAIRE RAISONNÉ DES SCIENCES, DES ARTS ET DES MÉTIERS, vol. IX (Denis Diderot \& Jean le Rond D'Alembert eds., 1765), http://enccre.academiesciences.fr/encyclopedie/article/v9-1848-187/ (my translation).

117 Supplice, in ENCYCLOPÉDIE, OU DICTIONNAIRE RAISONNÉ DES SCIENCES, DES ARTS ET DES MÉTIERS, vol. XV (Denis Diderot \& Jean le Rond D’Alembert eds., 1765), http://enccre.academiesciences.fr/encyclopedie/article/v15-2262-0/ (my translation).

118 Delia, supra note 115, at 100-03.

119 Assassinat, in SuPPLÉMENT À L'ENCYCLOPÉDIE, OU DICTIONNAIRE RAISONNÉ DES SCIENCES, DES ARTS ET DES MÉTIERS vol. I (Jean-Baptiste Robinet ed., 1776-77), https://gallica.bnf.fr/ark:/12148/bpt6k50550x/f661.image (my translation).

120 See ZIMRING, supra note 21, at 28-29.

121 Assassinat, in SuPPLÉMENT À L'ENCYCLOPÉDIE, supra note 119.

122 Delia, supra note 115, at 100-01. 
fellow encyclopédistes, he deemed executions necessary unless lifelong forced labor proved a more effective deterrent. ${ }^{123}$ Diderot's reasoning did not reflect empathy. Rather, he shrewdly exposed contradictions in the sensibilities of Beccaria, who had denounced the cruelty of executions before lauding the cruelty of lifelong forced labor as an alternative: "I observe that [Beccaria] abandons, with reason, his principle of mildness and humanity toward the criminal." ${ }^{24}$ Diderot equally signaled support for retribution in contending that it is "natural that the laws have ordered the murder of the murderer." ${ }^{\prime 25}$ His perspective was largely rooted in Rousseau's view that the social contract empowers the state to execute wrongdoers. ${ }^{126}$

In The Social Contract (1762), Rousseau nonetheless expressed ambivalence about the death

penalty. ${ }^{127}$ At the outset he argued that it may be necessary to preserve order. To avoid becoming "the victim of an assassin," the Swiss philosopher wrote, "one consents to die if one becomes an assassin." 128 Conversely, Beccaria framed capital punishment as "a war of the nation against a citizen" who never granted the state the power to take his life someday. ${ }^{129}$ But it would be a mistake to reduce the divergence between Beccaria and Rousseau as one between an abolitionist and a retentionist. Both converged in expressing moral reservations about the death penalty and calling for its limitation. Indeed, in the aforesaid passage Rousseau hastened to add that "frequent harsh punishments are a sign of weakness or laziness in the government. There is not a single wicked man who could not be made good for something. One only has the right to put to death, even as an example, someone who cannot be preserved without danger." ${ }^{30}$ Rousseau thus conciliated humanistic and utilitarian arguments in a polyvalent analysis: the death penalty is inhumane, except if incapacitation is impossible.

The Encyclopédie also captures the weight of Montesquieu's influence by reprising his justification of execution as "a punishment founded on reason, and drawn from the very source of

\footnotetext{
${ }^{123}$ LE NAOUR, supra note 67, at 25, 31-32.

124 Denis Diderot, Notes sur le Traité des délits et des peines, in CEuvres complÈtes De Diderot: Revues SUR LES ÉDITIONS ORIGINALES vol. IV 63, 67 (Jules Assézat ed., 1875) (my translation).

${ }^{125} \mathrm{Id}$. at 68.

${ }^{126} \mathrm{Id}$. at 67; LE NAOUR, supra note 67, at 25, 31.

127 LE NAOUR, supra note 67, at 23-24.

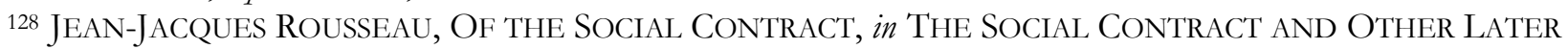
POLITICAL Writings 39, 64 (Victor Gourevitch trans. \& ed., 2003).

129 BECCARIA, supra note 23 , at 48.

${ }^{130}$ ROUSSEAU, supra note 128, at 65.
} 
good and evil," which is "the remedy, as it were, of a sick society." 131 This passage should not eclipse how Montesquieu helped steer a paradigm shift. Montesquieu was not an abolitionist but he emphatically called for milder punishments, thereby inspiring Beccaria and other reformers. ${ }^{132}$ In The Spirit of the Laws, Montesquieu proclaimed that " $[\mathrm{t}]$ he severity of punishments is fitter for despotic governments, whose principle is terror, than for a monarchy or republic, whose spring is honour and virtue." ${ }^{133}$ Montesquieu proposed a norm that has become a foundation of modern justice"proportion in punishments." 134 "It is a great abuse among us to condemn to the same punishment a person that only robs on the highway and another who robs and murders," he underscored. ${ }^{135}$

Furthermore, Montesquieu's humanistic sensibilities led him to encourage rulers to spare wrongdoers' lives: "So many are the advantages which monarchs gain by clemency, so greatly does it raise their fame, and endear them to their subjects, that it is generally happy for them to have an opportunity at displaying it; which in this part of the world is seldom wanting." 136 Providing diverse historic examples, he cautioned against executions: "The Emperor Maurice made a resolution never to spill the blood of his subjects. ... Isaac Angelus took an oath that no one should be put to death during his reign." 137

Montesquieu equally denounced the inhumanity and inutility of torture, demanding its abolition: "So many men of learning and genius have written against the custom of torturing criminals, that after them I dare not presume to meddle with the subject. I was going to say that it might suit despotic states . . but Nature cries out aloud, and asserts her rights." 138

The Spirit of the Laws is a prefiguration of Beccaria's polyvalent abolitionist rhetoric. "Mankind must not be governed with too much severity," Montesquieu explained, adding that wrongdoing "proceed[s] from the impunity of criminals, and not from the moderation of punishments." 139 In the same passage he offers thoughts on optimal deterrence. ${ }^{140}$ While Montesquieu does not call for the

131 Montesquied, The Spirit of The Laws 225 (trans. Thomas Nugent \& J.V. Prichard, 1900); Chevalier Louis de Jaucourt, Crime (Droit naturel), in ENCYClOPÉDIE, OU DICTIONNAIRE RAISONNÉ DES SCIENCES, DES ARTS ET DES MÉTIERS, vol. IV (Denis Diderot \& Jean le Rond D’Alembert eds., 1754), http:/ / enccre.academiesciences.fr/encyclopedie/article/v4-1117-1/.

132 See, e.g., BECCARIA, supra note 23, at 6, 8.

133 MONTESQUIEU, supra note 131, at 99.

${ }^{134} \mathrm{Id}$. at 109.

$135 \mathrm{Id}$. at 110 .

${ }^{136} \mathrm{Id}$. at 114 .

${ }^{137} \mathrm{Id}$.

${ }^{138}$ Id. at 111-12.

${ }^{139} \mathrm{Id}$. at 102 .

140 Id. at 102-03. 
abolition of capital punishment, unlike torture, he stresses that it is inhumane to execute wrongdoers in many instances, just as it is ineffective.

Once Beccaria made his plea for abolition in 1764, he caught the eye of another beacon of the Enlightenment. Voltaire crafted a lengthy commentary to the French translation of On Crimes and Punishment. Hoping that Beccaria's treatise "might soften the barbarities that linger in the jurisprudence of so many nations," 141 Voltaire began by evoking the predicament of an indigent woman condemned to die for abandoning her newborn. "[D]oes the death of the child justify the death of the mother?" Voltaire protested that "where charity is lacking, the law is always cruel." "True jurisprudence aims to prevent the crimes," not to repress them harshly. ${ }^{142}$

Employing a polyvalent rhetoric, Voltaire called for a paradigm shift to end cruel punishments while marshaling administrative, procedural, and utilitarian concerns. In particular, he proposed humane norms to reframe criminal law: vengeful retribution is an illegitimate justification for punishment; ${ }^{143}$ the sentence must be proportional to culpability; ${ }^{144}$ youth is a mitigating circumstance; ${ }^{145}$ and when the law is ambiguous "the judge should pass the mildest punishment without any hesitation, because he is a man," 146 which in modern language means "because he is human." Voltaire's vision encompassed procedural fairness, too, as he stressed that the accused should have a chance to defend themselves, including with counsel, and that exonerated innocents should receive reparations. ${ }^{147}$ Like Beccaria, ${ }^{148}$ Voltaire recommended lifelong forced labor as an alternative to death given its greater utility to the state. ${ }^{149}$ This utilitarian approach equally led Voltaire to suggest that executions may be counterproductive, as "a severe law sometimes produces crimes," 150 or useless,

141 Voltaire, Commentary on the BoOK ON CRIMES AND Punishments, By A Provincial LaWyer (1766), in On Crimes and Punishments AND Other Writings 113, 113 (Aaron Thomas ed., Aaron Thomas \& Jeremy Parzen trans., 2008).

${ }^{142} I d$. at 114 .

143 Id. at 122 .

${ }^{144}$ Id. at $114,131-32,140$.

${ }^{145} \mathrm{Id}$. at 121.

$146 \mathrm{Id}$.

${ }^{147} I d$. at 130, 146-50; Voltaire, Prix De LA JustiCe ET DE L'HUMANité 101-02 (1778).

148 BECCARIA, supra note 23 , at $50-51$.

149 Voltaire, COMMentary ON THE BoOK ON CRIMES AND PUNISHMENTS, supra note 141, at 213-14; VOLTAIRE, PRIX DE LA JUSTICE ET DE L'HUMANITÉ, supra note 147, at 13, 17-18.

150 Voltaire, COMMENTARY ON THE BOOK ON CRIMES AND PUNISHMENTS, supra note 141, at 140. 
because in countries implementing alternatives "[c]rimes did not increase as a consequence of this humane approach. ${ }^{\prime 151}$ For analogous reasons, Voltaire excoriated torture and corporal punishments. ${ }^{152}$

Voltaire's commentary did not express categorical opposition to capital punishment, leaving doubt about his ultimate conclusion, but denounced its cruelty and called for radically limiting its use: "[H] umanity, which is stronger than the law, should spare the life of those for whom the law itself has ordained death." 153

A decade after his commentary on Beccaria's treatise, Voltaire took a more overtly abolitionist position. He organized a competition to provide a monetary prize for the best draft legislation on criminal law, procedure, and evidence. ${ }^{154}$ The philosopher accompanied the competition announcement with more reflections on humane and utilitarian justice, including "proportional" punishments that would blend "mildness" and "swiftness" for the benefit of "liberty and humanity." 155 Disapproving the adage of an eye for an eye, he insisted that executing a murderer will never bring a victim back. ${ }^{156}$ Voltaire urged competitors to consider Beccaria's abolitionist plea and assess "whether it is indeed reasonable that magistrates commit homicide to teach men to hate homicide." ${ }^{157}$ In Voltaire's eyes incapacitation might be the lone justification for an execution if no alternative is available, thereby taking the life of a "rabid dog" to "save the life of the greater number." 158 Still, Voltaire ended his pamphlet by urging rulers to treat criminals in the same way as Louis XVI, then the king of France, treated military deserters_-by sparing their lives and enabling them to make amends. ${ }^{159}$ The law should not search for "pretexts to spill blood." 160

Overall, the prior sources show that a polyvalent abolitionist discourse had emerged by the late eighteenth century. Beccaria is the main archetype of this rhetoric. We saw that his humanistic sensibilities and calls for reform reflected a broader normative shift that had already emerged several

151 Id. at 129.

152 Id. at 131-32; VOLTAIRE, PRIX DE LA JUSTICE ET DE L'HUMANITÉ, supra note 147, at 103-05, $110-12$. Voltaire's abolition of torture differed from the modern notion of an inalienable human right in supporting an exception: the torture of Ravaillac, who assassinated Henry IV in 1610, so that Ravaillac may reveal any accomplices. VOLTAIRE, PRIX DE LA JUSTICE ET DE L’HUMANITÉ, supra note 147, at 105-06.

$153 \mathrm{Id}$.

154 VOlTAire, PRIX DE LA JUSTICE ET DE L'HUMANITÉ, supra note 147, at 2. On Voltaire's prize and praise of Beccaria, see LE NAOUR, supra note 67, at 36-37.

155 VOLTAIRE, PRIX DE LA JUSTICE ET DE L'HUMANITÉ, supra note 147, at 2 (my translation).

156 Id. at 13.

157 Id. at 16.

158 Id. at $16-17$.

${ }^{159} \mathrm{Id}$. at $118-19$.

${ }^{160} \mathrm{Id}$. at 119. 
generations earlier in the Renaissance and Enlightenment, as the writings of Erasmus, Thomas More, Montaigne, and Montesquieu demonstrate. This discourse did not merely comprise concerns about the death penalty's ineffectiveness and unfair implementation. Philosophers equally marshaled moral and political objections to its inhumanity, cruelty, and impropriety-arguments akin to modern human rights abolitionism. Even though they did not demand outright abolition, Beccaria's predecessors contributed to the abolitionist movement's rise by demanding restrictions on capital punishment. In calling for abolition, Beccaria in turn influenced Voltaire, possibly the Supplement to the Encyclopédie, ${ }^{161}$ just as he would influence America's Founding Fathers, ${ }^{162}$ French revolutionaries, ${ }^{163}$ and beyond.

But how did this evolution in philosophical thought translate into concrete legal change? In 1765, Leopold II - then the Grand Duke of Tuscany and subsequently the Holy Roman Emperorbegan applying Beccaria's theory and granting clemency to all those sentenced to death in Tuscany. As Tuscany abolished capital punishment in 1786, Leopold declared: "It is with the greatest satisfaction for our paternal sentiments that we noticed that the mildening of punishments, combined with a fine attention in punishing crimes ... had considerably diminished the lesser ones and made rare those of an odious nature." ${ }^{164}$ In 1787, his brother Joseph II abolished the death penalty in Austria save for treason. ${ }^{165}$ Recalling how the path to abolition is not linear, Tuscany later reintroduced capital punishment but seldom applied it ${ }^{166}$ before Italy joined the abolitionist camp in $1947 .{ }^{167}$ Yet Beccaria's ideas would resound far beyond Italy.

\section{FROM THE AMERICAN ENLIGHTENMENT TO FURMAN}

This section examines the evolution of American abolitionism from the Enlightenment to Furman v. Georgia, the landmark 1972 Supreme Court decision that temporarily abolished capital punishment. ${ }^{168}$ We will see how generations of American reformers followed in Beccaria's footsteps by presenting a polyvalent critique of capital punishment's immorality, inequity, and inutility. While

\footnotetext{
161 Delia, supra note 115 , at 101-03.

162 See infra note 175.

163 See infra note 271.

164 LE NAOUR, supra note 67, at 42-43 (quoting ÉDOUARD DUCPÉTIAUX, DE LA PEINE DE MORT $345-46$

(1827)) (my translation). Accord JOHN D. BESSLER, CRUEL AND UNUSUAL: THE AMERICAN DEATH PENALTY AND THE FOUNDERS’ EIGHTH AMENDMENT 39, 46 (2012).

165 BESSLER, supra note 164 , at 46.

166 BESSLER, supra note 164, at 46; LE NAOUR, supra note 67, at 138.

167 AMNESTY INT'L, supra note 1.

168 Furman v. Georgia, 408 U.S. 238 (1972) (per curiam).
} 
humanistic claims are associated with modern European abolitionism, they actually played a significant role in the United States until the post-Furman era. This historical evidence further demonstrates that framing the death penalty as a violation of human rights and dignity is not a modern development. ${ }^{169}$ Rather, the main modern transformation lies in how these norms have become the official basis for abolition in Europe, following a long battle by abolitionists. ${ }^{170}$

Before its breakthrough in modern Europe, abolitionism initially made headway in the first democracy born of Enlightenment ideas: the United States. Its foundation enabled the concrete application of Enlightenment principles, although it would be a mistake to imagine American reformers unimaginatively implementing European philosophers' views. The American Enlightenment was a period of vibrant intellectual life and innovation transcending European thought. ${ }^{171}$ It encompassed a tendency toward "mildness" and "sentimental humanism" in criminal punishment. ${ }^{172}$ The first "proto-prisons" aiming to rehabilitate inmates thus emerged in America in the 1780 s and 1790 s. ${ }^{173}$ In this period "the propriety of capital punishment for any crime, even murder, was a bitterly contested issue," as Stuart Banner's account describes. ${ }^{174}$ This partly reflected the influence of Beccaria, whom the Founding Fathers and contemporary Americans widely read. ${ }^{175}$

" $[R]$ ising political figures, such as James Madison and the future governor of New York DeWitt Clinton, favored abandoning capital punishment altogether. Others, such as Thomas Jefferson and Benjamin Franklin, advocated eliminating the death penalty for all crimes others than murder," Banner notes. ${ }^{176}$ The Founding Father Benjamin Rush, a leading abolitionist, framed his position in both normative and practical terms, stressing "[h]umanity and reason." ${ }^{177}$ The focus on the root social causes of crime, prefigured centuries earlier in Thomas More's Utopia, ${ }^{178}$ gained traction during the American Enlightenment. The notion that wrongdoers were not inherently evil buoyed Rush and fellow abolitionists, who demanded that laws punish both more humanely and effectively. ${ }^{179}$

\footnotetext{
169 See supra Section I.

170 See infra Section V.

171 Caroline Winter, American Enlightenments 12 (2016). See also Henry F. May, The EnLightenMent in AMERICA (1976); Robert A. FERguson, THE AMERICAN ENLIGHTENMENT: 17501820 (1997).

172 Kleinfeld, supra note 78, at 936.

173 Ashley T. Rubin, Prison History, Oxford ResearCh ENCYClopedia of CRiminology 1, 6 -7 (2018).

174 BANNER, supra note 60, at 88 (emphasis in original).

${ }^{175}$ Id. at 91-94; BESSLER, supra note 164, at ch. 2; MAY, supra note 171, at 118.

176 BANNER, supra note 60, at 88.

177 Id. (quoting LETTERS OF BENJAMIN RuSH 628 (Lyman H. Butterfield ed., 1951)).

178 See supra note 92 and accompanying text.

179 BANNER, supra note 60, at 102-11.
} 
In the final decades of the eighteenth century, reformers in diverse American states therefore sought to limit the death penalty's scope. By 1798, five states had abolished it for all crimes besides murder. ${ }^{180}$ Even if they did not demand full abolition, reformers commonly found broad use of capital punishment "barbaric" or "sanguinary." 181 The humanistic outlook of those who urged downright abolition is inferable from accusations portraying them as naively "sentimental" and "soft," if not "feminine," for empathizing with criminals. ${ }^{182}$ Empathy was not strictly limited to abolitionist circles. As in contemporary France, ${ }^{183}$ the automatic death penalty for certain crimes periodically led American juries to acquit defendants out of sympathy. ${ }^{184}$ As Banner explains, "much of the motivation for the invention of the prison arose from the growing distaste for executing burglars, robbers, rapists, and the like." 185

In 1847, this gradual humanistic and utilitarian evolution led Michigan to abolish capital punishment, where it has never been reintroduced. ${ }^{186}$ Few executions are documented in this region beforehand. ${ }^{187} \mathrm{~A}$ legislative committee had recommended abolition, insisting that "no man hath the power to destroy life but by commission from God." The committee added that executions slow the legal process, are irreversible, and could kill innocents. ${ }^{188}$

Sojourner Truth and fellow Michigan abolitionists subsequently militated against attempts to reestablish capital punishment. Truth, a former slave who became a key figure of movements for the emancipation of black people and women, had settled in Michigan. In 1881, she appeared before its legislature and said a movement to reintroduce the death penalty "shocked me worse than slavery." Deeming any execution state murder, she proclaimed: "When a man kills another in cold blood, and you hang him, then you murder in cold blood also... . I am against it!” According to Truth, executions outrage principles of Christian compassion. ${ }^{189}$ Furthermore, in 1891, Thomas M. Cooley, a prominent

180 Id. at $94-98$.

$181 \mathrm{Id}$. at $94-95,98$.

$182 \mathrm{Id}$. at 106, 126-27.

183 LE NAOUR, supra note 67, at 40, 91.

184 BANNER, supra note 60, at 91, 97; JOHN F. GALLIHER ET AL., AMERICA WiTHOUT THE DEATH PENALTY: STATES LEADING THE WAY 36 (2002).

185 BANNER, supra note 60, at 99.

186 The law entered into force on March 1, 1847 after being voted in 1846. Eugene G. Wanger, Historical Reflections on Michigan's Abolition of the Death Penalty, 13 T.M. COOLEY L. REV. 755, 765 n.59 (1996).

187 GALLIHER ET AL., supra note 184, at 11.

188 Id. at 15 (quoting Mi. LEgislature, House MAJORITY REPORT OF THE SELECT COMMITTEE ON ABOLISHMENT OF CAPITAL PUNISHMENT 2 (1844)).

189 Sojourner Truth, Lecture in Lansing, Mi., June 3, 1881, in SOJOURNER TRUTH AS OrATOR 135, 135 (Suzanne Pullon Fitch \& Roseann Mandziuk eds., 1997). 
Michigan judge and academic, specified that "the fundamental objection" expressed against capital punishment was normative, namely "the sacredness of life" and the bad example of a government that kills "without fear or horror."190 The situation of Michigan illustrates how nineteenth-century American abolitionists did not merely present practical or utilitarian objections to capital punishment, as many insisted on its inhumanity in terms foreshadowing the right to life in modern conceptions of human rights and dignity.

Wisconsin thereafter abolished capital punishment in $1853 .{ }^{191}$ A journalist who observed legislative hearings reported that the debate had a moral dimension; and personally deplored the "barbarities" of capital punishment, calling instead for "brotherhood" and "love."192 Administrative problems also spurred reform, including alleged ethnic bias, followed by a botched hanging, in the prominent case of John McCaffary, an Irish immigrant. ${ }^{193}$ Administrative troubles likewise proved influential when Maine abolished capital punishment in 1887. In the run-up to reform, the execution of a black man, Clifton Harris, led to public outcry over discrimination. Evidence additionally suggested his innocence. Analogous problems surrounded the execution of Louis F.H. Wagner, a Prussian immigrant who vowed his innocence. Multiple botched hangings compounded these worries. ${ }^{194}$ Certain Maine abolitionists nonetheless blended practical concerns with normative ones, such as Tobias Purrington who labeled executions useless "vengeance." 195

Hence, reformers employed a polyvalent rhetoric in the three states that pioneered American abolitionism in the nineteenth century: Michigan, Wisconsin, and Maine. Abolitionists did not solely oppose capital punishment because of administrative, procedural, and utilitarian concerns. Much like European contemporaries, ${ }^{196}$ they also condemned its immorality, cruelty, and inhumanity. ${ }^{197}$ This humanistic dimension reflected a wider context, as the norm of "sympathy" played a key role in nineteenth-century U.S. reform movements, from abolishing slavery and capital punishment to

\footnotetext{
190 Wanger, supra note 186, at 769 (quoting ANDREW J. PALM, THE DEATH PENALTY 149-50 (1891)).

191 Wisconsin technically preceded Michigan in abolition for all crimes, as Michigan retained it for treason, although this exception has never been applied. GALLIHER ET AL., supra note 184, at 11, 31.

${ }^{192}$ Id. at 32 (quoting Carrie Cropley, The Case of John McCaffary, 35 WIS. MAG. OF HIST. 281, 288 (1951)).

${ }^{193} \mathrm{Id}$. at 34-36.

${ }^{194} \mathrm{Id}$. at $54-55$.

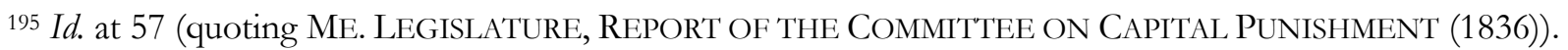

196 See infra Section III.

${ }^{197}$ For additional normative arguments against capital punishment in Michigan, see id. at 19, 28, in Wisconsin, see $i d$. at 34-35, and in Maine, see $i d$. at 71, 73, 75.
} 
uplifting working classes. ${ }^{198}$ A survey of America's intellectual debate in this period supports this conclusion.

Ralph Waldo Emerson was an abolitionist. He associated capital punishment with retrograde institutions like monarchy and feudalism. ${ }^{199}$ In 1867, Emerson optimistically proclaimed that "this country and this age belong to the most liberal persuasion." His conception of progress comprised "the abolition of capital punishment, and of imprisonment for debt; the improvement of prisons," among other ambitious reforms. ${ }^{200}$ In another lecture, Emerson backed the abolition of the death penalty and of "legal cruelties in the penal code," but lamented that politicians lacked the moral character and vision to achieve idealistic social changes. ${ }^{201}$ Although Emerson, Henry David Thoreau, and peers in the Transcendentalist movement hardly focused on capital punishment, they usually sympathized with abolition. ${ }^{202}$ Thoreau famously denounced the hanging of John Brown, the antislavery rebel, but this plea does not tell us his views on executions in general. ${ }^{203}$ However, Thoreau signed an 1849 petition protesting an execution in moral terms, casting it as "a crime in which we would under no circumstances participate, which we would prevent if possible and in the guilt of which we will not by the seeming assent of silence, suffer ourselves to be implicated." 204 The condemned was a black man and this likewise appeared to motivate Thoreau's position, given his concerns about racial injustice. ${ }^{205}$ His interest in the issue may have arisen at a young age, as he participated in a debate on abolition as a Harvard student. ${ }^{206}$ "[T] he gallows bear an ill name, and I think deservedly," he wrote later in life, expressing concern about the hanging of "many an innocent man." "The days of the gallows are numbered," he weighed, before alluding to "morbidly curious persons" who watch executions. ${ }^{207}$

198 Jane Bennett, Whitman's Sympathies, 69 POL. RES. Q. 607, 607 (2016).

199 Paul Christian Jones, Against the Gallows: ANTEBellum American Writers and the MOVEMENT TO ABOLISH CAPITAL PUNISHMENT 27 (2011).

200 Ralph Waldo Emerson, Progress of Culture, July 1867, in Collected works of Ralph Waldo EMERSON, VOLUME VIII: LETTERS AND SOCIAL Aims 108, 109 (Joel Myerson ed., 2010).

201 Ralph Waldo Emerson, Politics (1844), in Collected Works of Ralph Waldo Emerson, VOlume III, EsSAYS: SECOND SERIES 117, 122-23 (Alfred R. Ferguson, Jean Ferguson Carr \& Joseph Slater eds., 1983).

202 JONES, supra note 199, at 27-28.

${ }^{203}$ Henry David Thoreau, A Plea for Captain John Brown, Oct. 30, 1859, in THE Writings of Henry David THOREAU vol. X 197 (1893).

204 Ruth Robinson Wheeler, Thorean and Capital Punishment, 86 THOREAU SOC’Y BULL. 1, 1 (1964).

205 WALter Harding, THE Days OF HeNRY DaVID ThOREAU 314 (2013).

206 Id. at 41.

${ }^{207}$ In this journal entry, Thoreau compared the gallows to "the murderous Lincoln Bridge," where callousness precipitated numerous fatal accidents. Henry David Thoreau, Journal, Dec. 10, 1856, in THE WRITINGS OF 
Frederick Douglass, arguably the foremost African-American leader of the nineteenth century, identified the death penalty as a violation of "human rights." 208 Speaking for a group of abolitionists in Rochester, New York, Douglass evoked the right to life in modern European abolitionism by declaring: "[L]ife is the great primary and most precious and comprehensive of all human rights—that whether it be coupled with virtue, honor, or happiness, or with sin, disgrace and misery [it may not be] voluntarily destroyed [by] Government." Douglass expressed a religious conviction akin to the idea of inalienable human dignity, calling life "a right derived solely and directly from God," to wit the most "inviolable of all his gifts." ${ }^{209}$ Tellingly, Douglass did not focus these resolutions on the death penalty's racist application but on humanistic grounds.

Douglass was not alone in defending a two-fold abolitionism—of slavery and capital punishment. Although not all opponents of slavery shared this sentiment, anti-slavery newspapers commonly depicted enslaving and executing human beings as brutal tyranny. ${ }^{210}$ Other leading figures defended this dual abolitionism, including Wendell Phillips, ${ }^{211}$ William Lloyd Garrison, Henry Wadsworth Longfellow, and Lydia Maria Child, who considered hangings anti-republican and unchristian. ${ }^{212}$ Philipps notably applauded Michigan's abolition and felt that doing so nationwide would honor "civilization and Christianity." ${ }^{13}$ As for Child, among the most influential women thinkers of her age, she expressed widely-circulated thoughts on the gallows and the poor's harsh predicament. ${ }^{214}$ To Child, capital punishment was "savage," "barbarous," "ignominious," a "legalized state murder, in cold blood," inflicting "cruelty" for hollow "vengeance." 215 She witnessed the "disappointed rage" of a New York crowd that "felt cheated of a [public] hanging," because the condemned had committed suicide in his cell. Again evoking the right to life in modern human rights abolitionism, Child stressed: “To me, human life seems so sacred a thing, that its violent termination

HENRY DAVID THOREAU vol. XV 174, 175-76 (Bradford Torrey ed., 1906).

${ }^{208}$ Frederick Douglass, Resolutions Proposed for Anti-Capital Punishment Meeting, Rochester, N.Y., Oct. 7, 1858, in Frederick Douglass: Selected SPEECheS AND Writings 369, 371 (Philip S. Foner \& Yuval Taylor eds., 2000).

${ }^{209}$ Id. at 371.

210 John Cyril Barton, Literary ExeCutions: Capital Punishment and AMERiCAN Culture, 18201925 14-17, 182 (2014). Cf. BANNER, supra note 60, at 113, 136-37, 142-43.

211 Richard Hofstadter, The American Political Tradition 184 (1989); Dean Grodzins, Wendell Phillips, the Rule of Law, and Antislavery Violence, in Wendell Phildips, SOCIAL Justice, AND THE POWER OF THE PAST 89, 91, 94 (A.J. Aiséirithe \& Donald Yacovone, 2016).

212 BARTON, supra note 210, at 14-17, 182, 203, 206.

${ }^{213}$ Wendell Phillips Letter to William Lloyd Garrison, June 27, 1846, reprinted in LIBERATOR, July 3, 1846, at 107.

214 BARTON, supra note 210, at 63, 83-95.

${ }^{215}$ Lydia Maria Child, Letter XXXI, Nov. 19, 1842, in LETTERS From NEW YORK 220, 220-22 (1848). 
always fills me with horror ... . whether done contrary to law and custom, or according to law and custom." ${ }^{216}$ However, Child's fundamentally humanistic, religious, and political opposition to capital punishment did not preclude her from polyvalently expressing administrative and utilitarian concerns. She thus decried "the danger of convicting the innocent" based on "precarious" evidence. She denunciated arbitrariness since juries spared the lives of many offenders. Child added that executions foster crime by teaching violence and-implicitly channeling Beccaria and European abolitionismunderlined that "testimony from all parts of the world is invariable and conclusive, that crime diminishes in proportion to the mildness of the laws." 217

Several leaders of the contemporary women's rights movement likewise stood against capital punishment. ${ }^{218}$ Susan B. Anthony joined Frederick Douglass at the aforesaid Rochester anti-death penalty meeting in 1858. ${ }^{219}$ The suffragist Ida Husted Harper, whom Anthony entrusted as her biographer, described the position of Anthony and her peers regarding this hanging for homicide: "It was not that they doubted the [defendant's] guilt ... they were opposed to the principle of what they termed judicial murder." ${ }^{220}$ Elizabeth Cady Stanton, who led the National Woman Suffrage Association from 1869 to 1890, found executions dehumanizing. "It makes me shudder to think of the cruelties that are inflicted upon criminals in the name of justice," she deplored, labeling capital punishment "a relic of barbarism" and the gallows an instrument of "torture."221

A magisterial study by John Cyril Barton also offers innumerable examples of nineteenthcentury American authors decrying the death penalty's cruelty and immorality. Their stance reflected "the Enlightenment ideal of a less severe, more proportional government" and "a republican disdain for the so-called 'right' of a state to take its citizens' lives." Embodying this reformative spirit, works of literature called for limiting capital punishment or abolishing it altogether. ${ }^{222}$ In 1834 , an essay under the pen name Humanity proclaimed, "I am opposed to all executions, for crime, and especially to those which are made public." ${ }^{223}$ Barton explains that this statement "was far from radical for the

${ }^{216} I d$. at 221-22.

${ }^{217} \mathrm{Id}$. at 226, 230, 227 (quotes).

218 BARTON, supra note 210 , at 18-19.

${ }^{219}$ Douglass, supra note 208, at 369.

220 Ida Husted Harper, The Life And Work of Susan B. Anthony 164-65 (1899). See also id. at 309 (noting Anthony's support for abolition).

221 BARTON, supra note 210, at 18 (quoting Letter from Elizabeth Cady Stanton to Marvin H. Bovee, Aug. 1, 1868, in MARVIN H. BOVEe, Christ and the Gallows; OR, REASONS FOr THE AbOlition OF CAPITAL PUNISHMENT 173, 175 (1869)).

222 Id. at 6-7, 26 (quote), 260.

${ }^{223}$ Id. at 2 (quoting Humanity, Observations on the Curiosity of Those Who Go to Witness Public Executions, in THE 
period," as "[i]nfluential legislators and politicians, as well as prominent reformers, ministers, and writers, made such declarations."224

Humanity's essay prefaced a book that was among the favorites of Nathaniel Hawthorne. ${ }^{225}$ According to Barton, diverse elements suggest that Hawthorne supported capital punishment, despite reservations. ${ }^{226}$ But multiple other writers matched Humanity in repudiating this practice. For instance, John Neal, whose popular novel Logan (1822) featured hanging scenes, like many contemporary novels, ${ }^{227}$ expressed abolitionist convictions. Neal did not believe "in the wisdom of strangulation, for men, women, and children, however much they might seem to deserve it," adding that "the worst men have most need of repentance, and that they who are unfit to live, are more unfit to die."228

Walt Whitman, another prominent voice of the age, denounced the cruelty, inutility, and inequity of capital punishment. ${ }^{229}$ Despite urging empathy for crime victims, he was accused of naïve womanliness for being sentimental toward convicts. Co-opting these charges, he affirmed that sympathy reflected true religion. ${ }^{230}$ When Whitman claimed "we forget that [the criminal] is still a duplicate of the humanity that stays in us all," ${ }^{231}$ his rhetoric embodied Durkheim's aforesaid theory of penal mildness: "What concerns man concerns us all; because we are all men. The feelings protecting human dignity thus are personally dear to us." 232 Whitman contended that, "to a person of large mind, principles are regarded in their application to the widest humanity." Decrying the gallows_-"Monstrous!"- -he impugned partisans of "legal strangulation."233

A co-founder of the Brooklyn Association of the Death Penalty, Whitman reasoned that all citizens in a democracy are responsible for an execution by their government. ${ }^{234}$ A contemporary

RECORD OF CRIMES IN THE UNITED STATES v, xi (1834)). Other aspects of Humanity's reasoning are dated, such as the emphasis on phrenology. Id. at 1.

${ }^{224} \mathrm{Id}$. at 2.

225 BARTON, supra note 210 , at 1.

${ }^{226} I d$. at 49, 138-42, 152, 164-65, 172. Herman Melville shared reservations toward capital punishment-a recurrent theme in his writing-but did not explicitly oppose it. Id. at 176, 185-86, 193, 211-12, 219.

${ }^{227} I d$. at 56, 63, 98, 131, 171, 207, 265.

228 Id. at 32 (quoting JOHN NEAL, WANDERING RECOlLECTIONS OF A SOMEWHAT Busy Life: AN AUTOBIOGRAPHY 390 (1869)).

229 Jerome Loving, WALt Whitman: The SONG OF Himself 93-95 (2000).

230 Bennett, supra note 198, at 609-10.

${ }^{231}$ Id. at 610 (quoting Walt Whitman, Our Answer to a Reasonable Question, Mar. 24, 1846, in GATHERING OF THE FORCES, vol. I 104, 107 (Cleveland Rogers \& John Black eds., 1920)).

${ }^{232}$ Durkheim, supra note 26, at 88.

233 Walt Whitman, Hurrah for Choking Human Lives!, June 24, 1846, in GATHERING OF THE FORCES 107, supra note 231, at 107-08.

${ }^{234}$ BARTON, supra note 210, at 6, 51-54. 
Universalist pastor similarly qualified executions as state murders perpetrated in citizens' name. Certain U.S. abolitionists associated capital punishment with omnipotent European monarchies that callously eliminated their citizens. ${ }^{235}$ A generation earlier, Benjamin Rush had proclaimed that "[c]apital punishments are the natural offspring of monarchical governments," whereas republican governments "appreciate human life" and are capable of being "merciful." "An execution in a republic is like a human sacrifice in a religion," Rush stressed. ${ }^{236}$ From this angle, a sphere of individual rights protects citizens from their government. This rationale is analogous to the modern principle that, irrespective of their wrongdoing, prisoners possess inalienable human rights, including the right to life. ${ }^{237}$

The U.S. social debate would continue to evolve as the country marched toward modernity. By the late nineteenth century, abolitionists stopped insisting on certain religious claims, such as "the Sixth Commandment ('Thou shall not kill') and God's prohibition on Cain's execution for fratricide." They instead leaned toward "theories of biological or environmental determinism informed by new scientific and sociological approaches to criminal behavior," including statistical data. ${ }^{238}$

Overall, nineteenth century American death penalty debates prove both distant and familiar. Certain facets appear dated, like the weight of phrenology, a pseudoscience imputing criminality to the shape of people's skulls. ${ }^{239}$ At the same time, many statements for or against the death penalty in this epoch could have been written today, such as those urging mercy or retribution. ${ }^{240}$ While we should be wary of anachronisms, we should simultaneously avoid the fallacious assumption that modern controversies are entirely new. Besides, even obsolete aspects of the nineteenth-century debate have modern analogues. Phrenology stands repudiated, yet the science of the mind remains prominent in modern capital trials, as the role of psychiatric experts demonstrates. ${ }^{241}$ Biblical verses are not as omnipresent as they were yesteryear, ${ }^{242}$ but religious faith remains a factor in shaping attitudes toward the death penalty in a nation that remains highly devout, particularly in the South, the "Death Belt."243

${ }^{235} I d$. at 2, 6, 13.

236 Id at 35-36 (quoting Benjamin Rush, Considerations on the Injustice and Impolicy of PUNISHING MURDER BY DEATH 18-19 (1792)).

237 See ZIMRING, supra note 21, at 28-29.

238 BARTON, supra note 210, at 10.

239 BANNER, supra note 60, at 119-21.

240 See, e.g., id. at 106, 124-25. The same could be said about the relative familiarity of early twentieth-century debates. See, e.g., Capital Punishment (Letters to the Editor), THE SuRVEY, Apr. 1914, at 353.

241 See KAUFMAN, supra note 9, passim.

242 See, e.g., BANNER, supra note 60, at 116-18; BARTON, supra note 210, at 10.

243 JOUET, supra note 15, at 214-17 (examining religious attitudes toward punishment). 
As America entered the twentieth century, Clarence Darrow issued a clarion call revealing a continuity with nineteenth-century abolitionism. One of the most prominent lawyers in U.S. history, Darrow published a novel titled an Eye for an Eye (1905) casting executions as premeditated murders. ${ }^{244}$ In a public debate a few decades later, Darrow labeled them a "horrible" punishment and stressed: "I would hate to live in a state that I didn't think was better than a murderer." 245 The renowned orator deployed a polyvalent rhetoric in condemning the death penalty: "I am against it because I believe it is inhuman, because I believe that as the hearts of men have softened they have gradually gotten rid of brutal punishment, . . because I believe that it has no effect whatever to stop murder." ${ }^{246}$ Darrow's position again confirms that American abolitionists embraced arguments akin to modern human rights norms centering on the immorality of capital punishment: "If a State wishes that its citizens respect human life, then the State should stop killing;", 247 "Every human being that believes in capital punishment loves killing, and the only reason they believe in capital punishment is because they get a kick out of it;" 248 "In the end, this question is simply one of the humane feelings against the brutal feelings." ${ }^{249}$ Darrow's statements evoke how the death penalty inherently presents normative questions, even though they are often repressed in the modern American psyche given the emphasis on practical problems surrounding capital punishment. ${ }^{250}$

Fellow reformers maintained a polyvalent discourse, as illustrated by how a sociopolitical magazine in Darrow's time cited data on executions' lack of deterrence. For good measure, it added that executions are "anachronistic" and that abolition would benefit "humanity.",251

A few decades later, another influential American voice condemned the inhumanity, racism, and ineffectiveness of executions. "Since the purpose of jailing a criminal is that of reformation rather than retribution ... it is highly inconsistent to take the life of a criminal," Martin Luther King, Jr. argued. "Capital punishment is against the best judgment of modern criminology and, above all,

\footnotetext{
244 BARTON, supra note 210, at 249-53.

245 Debate: Resolved: That Capital Punishment Is a Wise Public Policy, Clarence Darrow, Negative, v. Judge Alfred J. Talley, Positive, LeAGue for Pub. Discussion 39 (1924).

${ }^{246} I d$. at 40.

${ }^{247} I d$. at 31.

248 Id. at 29.

${ }^{249} I d$. at 62. See also BARTON, supra note 210, at 234 (discussing Darrow's debate).

250 Diverse scholars have concluded that, irrespective of practical or procedural issues, whether to execute someone is a moral question. See Kleinfeld, supra note 78, at 986 ("the only kind of argument to have about capital punishment is a normative one”); Robert Weisberg, Deregulating Death, 1983 SUP. CT. REV. 305, 308 (1983) ("a judge or jury's decision to kill is an intensely moral, subjective matter").

251 Editorials, THE SurVEY, Apr. 1926, at 39-40.
} 
against the highest expression of love in the nature of God." ${ }^{252}$ On another occasion, King protested Alabama's discriminatory execution of a black juvenile for allegedly raping a white woman. King then appealed to "human dignity" and suggested that the juvenile's potential innocence should not obscure fundamental moral objections to capital punishment. ${ }^{253}$

In practice, however, the stances of Darrow, King, and fellow abolitionists seldom reflected majority opinion, which impeded reform. Abolition nonetheless advanced under the Progressive movement in the late nineteenth and early twentieth centuries. Ten states voted it between 1897 and 1917, although eight reintroduced capital punishment by the end of the 1930s. ${ }^{254}$ The number of abolitionist states would stagnate, reaching a dozen by $1972 .{ }^{255}$ Meanwhile, the number of state executions gradually plummeted from 1,523 in the 1930s to 192 in the $1960 \mathrm{~s}^{256}$ This might have been less due to a societal rejection of capital punishment than to the U.S. Supreme Court's growing willingness to regulate its administration. ${ }^{257}$ Still, polls showed declining support. ${ }^{258}$ By 1972, a polyvalent abolitionist discourse had entered the Democratic Party Platform, which underlined the death penalty's cruelty, inequity, and uselessness: "We believe that the quality of justice will be enhanced by: ... Abolishing capital punishment, recognized as an ineffective deterrent to crime, unequally applied and cruel and excessive punishment."259 The California Supreme Court also adopted a polyvalent reasoning in its landmark decision abolishing capital punishment under the state conclusion, stressing "it is incompatible with the dignity of an enlightened society to attempt to justify the taking of life for purposes of vengeance." 260

252 Advice for Living, EbOnY, Nov. 1957, available at MArTin Luther King, JR. PAPERs Project, http://okra.stanford.edu/transcription/document_images/Vol04Scans/305_Nov-

1957_Advice\%20for\%20Living.pdf.

${ }^{253}$ Martin Luther King, Jr., Statement at the Prayer Pilgrimage Protesting the Electrocution of Jeremiah Reeves, Montgomery, Ala., Apr. 6, 1958, available at MARTin Luther King, JR. PAPERS Project, http://okra.stanford.edu/transcription/document_images/Vol04Scans/396_6-Apr-

1958_Statement \%20Delivered\%20-\%20Jeremiah\%20Reeves.pdf.

${ }^{254}$ John F. Galliher et al., Abolition and Reinstatement of Capital Punishment During the Progressive Era and Early 20th Century, 83 J. CRIM. L. \& CriminOlogy 538, 541, 558-59 (1992).

255 U.S. DEP'T OF JusT., Historical Corrections Statistics in the United States, 1850-1984 13 (1986).

256 Id. at 10.

257 BANNER, supra note 60, at 230.

${ }^{258} I d$. at 240.

259 Democratic Party Platform, July 10, 1972, https://www.presidency.ucsb.edu/documents/1972democratic-party-platform.

${ }^{260}$ California v. Anderson, 493 P.2d 880, 896 (Cal. 1972). A few months later voters overturned Anderson in a state ballot proposition. EVAN J. MANDERY, A WILD JUSTICE: THE DEATH AND RESURRECTION OF CAPITAL PUNISHMENT IN AMERICA 254-55 (2014). 
Finally, or so it seemed, the U.S. Supreme Court put an end to the death penalty in Furman $v$. Georgia (1972). ${ }^{261}$ Experts thought that America had firmly entered the abolitionist camp. ${ }^{262}$ Instead, the Justices soon reauthorized executions in Gregg v. Georgia (1976). ${ }^{263}$ Today, America is the only retentionist Western democracy. European law has notably concluded that any execution is a human rights violation. We will later return to Furman and how the American debate evolved in its aftermath. $^{264}$

At this stage, our examination of the American landscape from the late eighteenth century to the 1970s demonstrates that generations of abolitionists blended a humanistic and practical discourse. One can find in this period a prefiguration of modern American abolitionism's focus on administrative, procedural, and utilitarian problems. By the same token, our survey documents how past American reformers regularly denounced the cruelty and inhumanity of the death penalty_killing prisoners is wrong per se-in language evoking human rights claims that have cemented abolition in modern Europe. The striking reticence of modern American reformers to use a humanistic discourse has obscured the past; and may have contributed to cultural essentialism assuming that such humanistic sensibilities are fundamentally "European" and not "American." Moreover, the past American landscape shows that human rights objections were not suddenly born around the 1970s in Western Europe. ${ }^{265}$ Rather, the emergence of modern democracy in the United States saw the continuation of a normative evolution in criminal punishment since the Renaissance and the Enlightenment. We will now see that, up until Furman, Europe charted a path toward abolition that was closer to the American experience than is commonly believed.

\section{FROM THE FRENCH REVOLUTION TO ABOLITION}

This section pivots toward Europe to assess how its abolitionist movement evolved since the Enlightenment. While an overview of all European nations is beyond this Article's scope, France offers instructive points of comparison to America. Enlightenment ideals shaped both nations,

\footnotetext{
${ }^{261}$ Furman v. Georgia, 408 U.S. 238 (1972) (per curiam).

262 GARLAND, supra note 12, at 229; GARRETT, supra note 10, at 81; STEIKER \& STEIKER, COURTING DEATH, supra note 8, at 50; FrankLIN E. ZIMring \& GORDON HAWIKINS, CAPITAL PUNISHMENT AND THE AMERICAN AGENDA 37-38 (1986).

263 Gregg v. Georgia, 428 U.S. 153 (1976) (plurality opinion).

264 See infra Section V.

265 See supra Section I.
} 
culminating in revolutions in the same period. ${ }^{266}$ Despite the emergence of vibrant abolitionist movements in each country in the eighteenth century, they later became laggards in abolitionism. In 1981, France became the last Western European democracy to abandon capital punishment, just as retentionist America was increasingly isolated among comparable nations. ${ }^{267}$ A comparison of both nations therefore illuminates how abolitionists defended their cause in the face of adversity.

To numerous scholars, "the French Revolution and the fall of the Bastille came to symbolize the meanings of modern history." 268 Before France's revolution degenerated into the Terror and some 17,000 death sentences, ${ }^{269}$ it matched the American Revolution in embodying Enlightenment reformism. Like their American peers, ${ }^{270}$ French revolutionaries widely read Beccaria, whose precepts influenced their Declaration of the Rights of Man and the Citizen (1789). ${ }^{271}$

A commission on penal reform subsequently presented its conclusions to the National Assembly in 1791. Le Pelletier de Saint-Fargeau, who headed the commission, proposed to replace capital punishment with imprisonment. Unlike past abolitionists' calls for lifelong forced labor, he envisioned a form of rehabilitation under which sentences could vary between twelve and twenty-four years. Before imprisonment, however, wrongdoers would be exhibited on a plaza for public shaming and deterrence. Exhibiting the spirit of the day, the commission nonetheless proposed to retain executions for political crimes. ${ }^{272}$

The vote failed, despite the exhortations of Adrien Duport. An architect of the Declaration of Rights' bar on excessive punishments, Duport invoked Montesquieu and Beccaria when contending that cruel punishments encourage crime. ${ }^{273} \mathrm{He}$ equally proposed reframing the penal code with an

\footnotetext{
266 See generally DUNN, supra note 18; DENIS LACORNE, L'INVENTION DE LA RÉPUBLIQUE (1991).

267 See AMNESTY INT'L, supra note 1.

${ }^{268}$ W. B. Carnochan, The Literature of Confinement, in OXFORD HISTORY OF THE PRISON 381, 387 (Norval Morris \& David J. Rothman eds., 1995).

${ }^{269}$ DUNN, supra note 18, at 92; LE NAOUR, supra note 67, at 60; Jennifer Heuer, Did Everything Change? Rethinking Revolutionary Legacies, in OXFORD HANDBOOK OF THE FRENCH REVOLUTION 626, 635 (David Andress ed., 2015).

270 See supra note 175.

271 CÉCILE BArberger, Droit PÉNAl 5 (1997); Le NAOUR, supra note 67, at 22-39, 42-43, 53; MARCEL Morabito, Histoire CONSTitutionnelle De la FranCE, DE 1789 À nOS JOURS 63 (2016); Mireille Delmas-Marty, La jurisprudence du Conseil constitutionnel et les principes fondamentaux du droit pénal proclamés par la Déclaration de 1789, in LA DÉCLARATION DES DROITS DE L'HOMME ET LA JURISPRUDENCE 151, 152, 163 (1989).

${ }^{272}$ LE NAOUR, supra note 67, at 48-49.

${ }^{273} I d$. at 47, 53. See also DÉCLARATION DeS Droits De L'HOMme ET DU CiTOYEN art. VIII (Fr. 1789) ("The Law must only establish strictly and evidently necessary punishments ....") (my translation).
} 
article banning any sentence violating "the respect for the dignity of the human species." ${ }^{274}$ Still, the National Assembly reduced the number of capital crimes, abolished torture, and prohibited perpetual punishments in the name of rehabilitation. ${ }^{275}$

Robespierre would come to incarnate the glaring contradictions between the French Revolution's ideals and its carnage. Ironically, Robespierre deemed himself an opponent of capital punishment. He fervently urged its abolition, calling it a useless atrocity violating the "dignity" of humankind. ${ }^{276}$ Meanwhile, Robespierre masterminded the execution of countless counterrevolutionaries. This contradiction partly stems from how Robespierre supported abolition-except for treason. Robespierre thus predictably demanded the beheading of Louis XVI, declaring that the king "must die so that the nation lives." 277 Condorcet, another prominent revolutionary and abolitionist, was more consistent in his convictions as he opposed the monarch's execution: “The punishment for conspirators is death. But this punishment is against my values. I will never vote it."278

The Terror came to an end with thermidor, the fall and beheading of Robespierre on July 28, 1794. This facilitated additional abolitionist proposals, leading to a compromise on October 26, 1795. Legislators voted abolition but stipulated that it would come into force once peace returned, namely at an indeterminate future date. ${ }^{279}$ This meant voting retention. The recurrent legislative debate nonetheless demonstrated that the death penalty's propriety preoccupied numerous French revolutionaries.

The fate of abolitionism was subsequently tied to the near-century of instability following the French Revolution, as the nation saw a succession of political systems: the Directory (1795-99), Napoleon's various regimes (1799-1814, 1815), diverse monarchies (1814-15, 1815-48), the Second Republic (1848-52), and the Second Empire (1852-70). Abolitionism generally regressed under the

${ }^{274}$ Luc Heuschling, La dignité de l'être humain dans la jurisprudence constitutionnelle allemande, in LA DIGNITÉ SAISIE PAR LES JUGES EN EUROPE 115, supra note 29, at 119-20 (quoting Adrien Duport, Principes fondamentaux de la police et de la justice, présentés au nom du Comité de la Constitution, Dec. 22, 1789, Archives parlementaires 744,1 st series, tome $\mathrm{x}$ ) (my translation).

${ }^{275}$ LE NAOUR, supra note 67, at 53-55. On capital punishment and the revolution, see also HAMMEL, supra note 35, at 118-20; Jean Bloch-Michel, La peine de mort en France, in ALBERT CAMUS \& ARTHUR KoESTLER, RÉFLEXIONS SUR LA PEINE CAPITALE 199, 209-18 (2002).

276 LE NAOUR, supra note 67, at 36, 50-52, 63-64; Bloch-Michel, La peine de mort en France, supra note 275, at 211-13.

${ }^{277}$ Le NAOuR, supra note 67, at 60-61 (quoting Le MONITEUR UNIVERSEL 648, Dec. 3, 1792) (my translation). 278 Id. at 63-64 (quoting ELIZABETH BADINTER \& ROBERT BADINTER, CONDORCET 211 (1988)) (my translation).

${ }^{279} \mathrm{Id}$. at $69-77$. 
most authoritarian systems, when the number of capital crimes grew. ${ }^{280}$ The Napoleonic penal code even reintroduced corporal punishments in 1810, especially for parricides who would have their fists cut off before being executed. This practice was eliminated in 1832, alongside branding. ${ }^{281}$ French reformers still kept demanding the limitation or abolition of capital punishment. For instance, the Société de morale chrétienne organized in 1826 a competition rewarding the most convincing abolitionist argument. Charles Lucas, an attorney, won by declaiming the inherent injustice of an execution. ${ }^{282}$ The advent of the July Monarchy (1830-48) under Louis-Phillippe, the so-called Citizen King, enabled a reduction in capital punishment's scope. ${ }^{283}$ During the July Revolution (27-29 July, 1830) that gave rise to this constitutional monarchy, reformers proposed abolishing the death penalty to herald a new age. Among them stood the Marquis de Lafayette, who decades earlier had fought alongside American revolutionaries as a protégé of George Washington, before becoming a French revolutionary. France's ensuing political turmoil led him to flee and be imprisoned in Austria for five years. ${ }^{284}$ Lafayette regretted that the French Revolution failed to abolish capital punishment and his experiences made him mindful that criminal punishments could serve to repress dissidents: "[S]ince our political storms I feel an insurmountable horror for the death penalty." Besides underlining the risk of executing innocents, Lafayette cast abolition as a "grand act of humanity." 285 Other influential voices then espoused abolitionism, such as Alphonse de Lamartine, a famous poet and legislator, who disapproved capital punishment as sanguinary, useless, and illegitimate vengeance. The Société de morale chrétienne collected 18,000 signatures for an abolitionist petition. King Louis-Philippe lauded public enthusiasm for the cause, declaring in 1830: "Regarding the abolition of the death penalty, I am disposed to it due to a conviction that I have held my entire life. Your wish is mine, and I will put all my efforts into its realization." ${ }^{286}$ In reality, it would never be abolished in his reign of nearly two decades. Louis-Philippe's words may appear hypocritical but they reveal a chronic normative debate about the death penalty's inhumanity.

\footnotetext{
280 See generally LE NAOUR, supra note 67, at 77-83, 94-110.

281 Bloch-Michel, La peine de mort en France, supra note 275, at 218, 223.

282 LE NAOUR, supra note 67, at 96.

283 Id. at $111-14$.

284 DUNN, supra note 18, at 4-5, 13-17.

285 MARQUis DE LAFAYETTE, MÉmOIRES, CORRESPONDANCES ET MANUSCRITS DU GÉNÉRAL LAFAYETTE PUBLIÉS PAR SA FAMILLE vol. VI 426-27 (1838) (my translation). See also DUNN, supra note 18, at 15; LE NAOUR, supra note 67, at 102.

286 LE NAOUR, supra note 67, at 118 (quoting J. CYPRIEN ROUMIEU, PLUS D’ÉCHAFAUDS! OU DE L'ABOLITION IMMÉDIATE ET ABSOLUE DE LA PEINE DE MORT 264 (1833)) (my translation).
} 
Victor Hugo would then personify abolitionism. In 1829, he published The Last Day of a Condemned Man, an avant-garde first-person narrative aiming to have readers identify with someone sentenced to death. It is unclear whether the narrator is guilty or innocent, or even what he is accused of. The novella is sophisticated but its message is straightforward: any execution is inherently cruel and inhumane. ${ }^{287}$ Hugo's sensibilities paralleled those of nineteenth-century American intellectuals who demanded abolition. ${ }^{288}$

Hugo was not merely a prominent author, as he was a legislator under the July Monarchy and the ensuing Second Republic. ${ }^{289}$ While he urged abolition before the National Assembly, ${ }^{290}$ his indefatigable calls for penal reform extended beyond capital punishment. In 1847, Hugo presented a detailed perspective evoking Durkheim's subsequent theory on the gradual mildening of punishments with the evolution from absolute monarchy to democracy. ${ }^{291}$ Indeed, Hugo described an historical shift from pre-modern justice centered on repression and deterrence toward the humanization and rehabilitation of prisoners. Citing Montesquieu, Beccaria and other thinkers, Hugo described how the prisoner has incrementally become "a creature worthy of attention even in his abasement." He proclaimed a right "that no sentence can take away: the right one can never lose, the right to become better." "Yes, the condemned is a man. . . even when one no longer respects the man, one must still respect his humanity," Hugo added. ${ }^{292}$ His reasoning closely mirrored modern conceptions of inviolable dignity rooted in empathy toward prisoners at an abstract human level. ${ }^{293}$

Multiple renowned French intellectuals and legislators shared Hugo's abolitionism. Lamartine proposed inaugurating the Second Republic with capital punishment's abolition in the name of the "inviolability of human life." 294 The relationship between abolitionism and sociopolitical transformations is likewise manifest in the declaration of the socialist leader Louis Blanc, who supported abolition to offer "humanity this joyous gift with the advent of democracy." 295 Victor

287 Victor Hugo, The Last Day Of a Condemned Man (Arabella Ward trans., 2009). See also HammeL, supra note 35, at 124-29 (arguing that Hugo's deontological, categorical approach to abolitionism foreshadowed the modern human rights standard).

288 See supra Section III.

289 Victor Hugo, in DiCTIONNAIRE DES PARLEMENTAIRES FRANÇAIS vol. III. 364 (Adolphe Robert, Edgar Bourloton \& Gaston Cougny eds., 1889-91).

${ }^{290}$ LE NAOUR, supra note 67, at 128-29.

291 See supra note 26 and accompanying text.

292 Hugo, Loi sur les prisons, supra note 30, at 143-44 (my translation).

293 See supra note 28 and accompanying text.

${ }^{294}$ LE NAOUR, supra note 67, at 124-25 (quoting AlPHONSE DE LAMARTINE, HisTOIRE DE LA RÉVOLUTION DE 1848, vol. I 337-38 (1859)) (my translation).

${ }^{295}$ Id. at 125 (quoting LOUIS VÉRON, MÉMOIRES D’Un BOURGEOIS DE PARIS, vol. V 97 (1857)). 
Schœlcher, the leading figure behind the abolition of slavery under the Second Republic, embraced abolitionism too. Like many other French reformers, he polyvalently blended normative, utilitarian, and administrative objections, including the bad example of a government that kills in vengeance, the risk of executing innocents, lack of deterrent value, and how murderers are underprivileged citizens whose education the government had utterly neglected. ${ }^{296}$

The Second Republic eventually rejected abolition by a 498-216 vote, although it eliminated executions for political crimes. ${ }^{297}$ The abolitionists' defeat was undeniable and subsequent events further undermined their cause. After Napoleon III toppled the Second Republic, France reverted to authoritarianism from 1852 to 1870 . Relative political stability would return with the Third Republic (1870-1940), which the historian François Furet identified as the actual end of the French Revolution and belated victory of its ideals following a near century of upheavals, backlashes, and regressions. ${ }^{298}$ Scholars generally regard the Third Republic as a period of incremental liberalism, equality, and human rights in France. ${ }^{299}$ As abolition slowly progressed in diverse parts of nineteenth-century Europe, French legislators made another push for it but, in 1894, failed in a 353-150 vote. ${ }^{300}$

Abolitionism enjoyed greater success in America than France in the nineteenth century. America's greater political stability then favored reform and the rule of law. Decentralization under federalism notably enabled abolition to prevail in Michigan and Wisconsin in 1847 and 1853, respectively. ${ }^{301}$ Despite these divergences, we have documented a striking convergence in abolitionism in both nations since the Enlightenment.

The relative convergence persisted as France entered modernity. The return of democracy following a quasi-century of post-revolutionary political instability led executions to decline, partly due to frequent executive clemencies. ${ }^{302}$ Famous French statesmen would demand abolition under the Third Republic, including Jean Jaurès, Léon Gambetta, Jules Ferry, Aristide Briand, and Georges

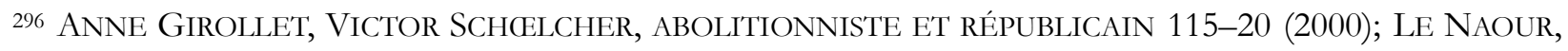
supra note 67 , at $128,132,136$.

${ }^{297}$ LE NAOUR, supra note 67, at 126-27, 130-31.

298 FRANÇOIS FURET, PENSER LA RÉVOLUTION FRANÇAISE 17 (1978).

${ }^{299}$ LACROIX \& PRANCHÈRE, supra note 53, at 5-10; FRÉDÉRIC LAZAUD, L’EXÉCUTION PAR LA FRANCE DES ARRÊTS DE LA COUR EUROPÉENNE DES DROITS DE L'HOMME 278-89 (2006); Georges Vedel, La place de la Déclaration de 1789 dans le 'bloc de constitutionnalité', in LA DÉCLARATION DES DROITS DE L'HOMME ET LA JURISPRUDENCE 35, supra note 271, at 37-39, 70.

${ }^{300}$ LE NAOUR, supra note 67, at 183-84, 187-88, 197.

301 See supra Section II.

302 LE NAOUR, supra note 67, at 185-86, 209, 221.
} 
Clemenceau. ${ }^{303}$ Humanistic sensibilities continued to influence abolitionism in this period, as illustrated by the stance of the socialist legislator Victor Dejeante in 1894: "It is in the name of humanity that we tell you: abolish the death penalty, scratch it from your legislation, make disappear this relic of barbarism." 304 As for Jaurès, a towering figure in the history of social democracy, he declared that it was unchristian to tell prisoners "that they are just scum and that they only deserve to have their lives taken." ${ }^{305}$

While the two world wars did not favor abolitionism in France, the number of executions ultimately dropped in the 1950s. In theory, the death penalty's scope expanded with the creation of new capital crimes like armed robbery. But France executed no one for this and the penalty was declining, as in Europe. ${ }^{306}$

These circumstances buoyed the longstanding abolitionist movement that had emerged during the French Revolution. A paradigm shift would occur when Parliament voted abolition in 1981 and when France subsequently insisted that any execution is a human rights violation. ${ }^{307}$ But the shift was more in the fact that this became the official discourse in Europe. As we saw, abolitionists in France, America, and beyond had long condemned the death penalty's inhumanity. As Zimring correctly hypothesized, human rights norms "were important motivations beneath the surface of death penalty debates long before they emerged in the aftermath of abolition." 308

In France at least, this paradigm shift did not occur despite an "absence of high levels of intellectual discussion on questions about capital punishment policy," 309 but partly because of this very intellectual debate. We saw that thinkers in France began expressing humanistic concerns about the death penalty centuries earlier, in the image of Montaigne, Montesquieu, Voltaire, French revolutionaries, Victor Hugo, and numerous other reformers.

The breakthrough toward abolition in postwar France marked the continuation of this longstanding intellectual and public debate. Illustratively, in 1952, the abolitionist movie Nous sommes

\footnotetext{
303 Id., passim.

304 Id. at 196 (quoting JOURNAL OFFICIEL, May 11, 1894, at 772).

305 Id. at 236-37 (quoting JOURNAL OFFICIEL, Nov. 18, 1908, at 2394).

306 Id. at 262-63, 279, 289.

307 ZIMRING, supra note 21, at 42-45.

${ }^{308} I d$. at 41 . See also supra note 73 and accompanying text.

309 ZIMRING, supra note 21, at 26. See also id. ("In the critical years of political change, there was little excitement and ferment in the abolitionist rhetoric and very little sustained debate . ...”).
} 
tous des assassins (Are We All Murderers?) enjoyed relative success. Directed by André Cayatte, this drama highlighted the cruelty of the execution process. ${ }^{310}$

In 1957, Albert Camus joined the fray in publishing Reflections on the Guillotine, an abolitionist manifesto. ${ }^{311}$ His two most prominent novels, The Stranger ${ }^{312}$ and The Plague, ${ }^{313}$ had previously depicted the inhumanity of capital punishment. Reprising an account from The Stranger, ${ }^{314}$ Camus began his manifesto by describing the reaction of his dismayed father who vomited upon returning from a public execution. ${ }^{315}$ Throughout Reflections on the Guillotine, Camus's rhetoric is highly normative and humanistic in condemning capital punishment: "that ritual act is horrible,"316 "primitive,"317 a "vile death" akin to "torture," 318 a "crude surgery," 319 "the most premeditated of murders" committed by "a monster" 320 "from a barbarous period" ${ }^{321}$ for "revenge." 322 The death penalty's uselessness is also a recurrent theme, as Camus is another archetype of polyvalent abolitionist rhetoric. He thus insisted on executions' lack of deterrent value ${ }^{323}$ and the risk of executing the innocent, interestingly citing a potential wrongful conviction in a U.S. capital case. ${ }^{324}$ This reference, much like American reformers' numerous citations to Reflections on the Guillotine in subsequent decades, exemplifies the transatlantic convergence in abolitionism in this epoch. ${ }^{325}$ Last but not least, Camus advanced that the death penalty

310 LE NAOUR, supra note 67, at 263-67; Bloch-Michel, La peine de mort en France, supra note 275, at 243.

311 Albert Camus, Reflections on the Guillotine, in Resistance, Rebellion, and Death 173 (Justin O’Brien trans., 1961).

312 Meursault, the narrator sentenced to death for murder, described the absurdity and cruelty of capital punishment. AlBerT CAMUS, THE STRANGER 106-11 (Matthew Ward trans., 1988) (1st French ed. 1942).

313 Jean Tarrou, one of the novel's main characters, repudiated his father because he was a prosecutor who sought the death penalty. Albert Camus, The Plague 189-95 (Robin Buss trans., 2002) (1st French ed. 1947).

314 CAMUS, THE STRANGER, supra note 312, at 110.

315 CAMus, RefleCtiOns ON THE GUILLOTINE, supra note 311, at 175-76.

316 Id. at 175.

317 Id. at 177.

318 Id. at 233.

${ }^{319} \mathrm{Id}$. at $185,233$.

320 Id. at 199.

321 Id. at 233.

322 Id. at $179,197$.

323 See, e.g., id. at 186-88, 193-94.

324 This is the case of Burton Abbott, whom California executed in 1957. Id. at 211-13.

325 See generally Arthur J. Goldberg \& Alan M. Dershowitz, Declaring the Death Penalty Unconstitutional, 83 HARV. L. REV. 1773, 1773 (1970) (America must "take what Camus called 'the great civilizing step' of abolishing the death penalty") (internal citation omitted); Daniel D. Polsby, The Death of Capital Punishment? Furman v. Georgia, 1972 SUP. CT. REV. 1, 3 (1972) ("While the haut monde read Camus and refined their thoughts on the sanctity of life, the machinist's wife read the newspapers and thought about how the world was going to hell."). 
deprives human beings of their "dignity," 326 which has become the official basis for human rights abolitionism in Europe. ${ }^{327}$

As intellectuals like Camus sought to put abolition on the political agenda, capital punishment gained public attention due to high-profile murder cases. ${ }^{328}$ In 1965, the father of a murdered child founded a pro-death-penalty organization that diverse public figures embraced. ${ }^{329}$ The killing of a prison guard and nurse in 1971 further galvanized death-penalty supporters. In 1976, the murder of a little boy received highly emotional news coverage in France, ${ }^{330}$ evoking the inflammatory reporting tied to the exceptional harshness of modern American criminal justice. ${ }^{331}$ That year the execution of Christian Ranucci for killing a young girl led to a vigorous social debate given his potential innocence and false confession. ${ }^{332}$ Gilles Perrault, the author of a 1978 book on the case-Le pull-over rouge ("The red sweater"), ${ }^{333}$ adapted in film the next year ${ }^{334}$ — testified before Parliament. ${ }^{335}$ Alongside innocence, the hearing addressed the morality of executions when a Catholic bishop testified in favor of abolition, despite acknowledging divisions within the Church. "[A] man cannot be reduced to the act he committed at a given time," Monsignor Fauchet pleaded, approving the ongoing "cultural" evolution away from executions. ${ }^{336}$

All this media coverage enhanced the public profile of a defense counsel-Robert Badinterwho would eventually become the most prominent French abolitionist. Badinter embarked on this path partly by happenstance. Initially a business lawyer, he once took on a capital case to replace an acquaintance. ${ }^{337}$ He ultimately represented defendants in multiple capital cases and regularly spoke for abolition in the media. ${ }^{338}$ While Camus might have become the most emblematic figure as France

\footnotetext{
326 CAMUS, REFLECTIONS ON THE GUILLOTINE, supra note 311, at 204.

327 See, e.g., Council of Europe \& European Union, Joint Declaration on the Death Penalty, supra note 5. 328 See generally HAMMEL, supra note 35, at 135-40.

329 Jean Bloch-Michel, Avant-propos de l'édition de 1979, in RÉFLEXIONS SUR LA PEINE CAPITALE 17, supra note 275 , at $19-20$.

330 LE NAOUR, supra note 67, at 295-307.

331 See Katherine BecketT \& Theodore Sasson, The Politics of Injustice 77-87 (2000); Garland, supra note 250, at 295.

332 Bloch-Michel, Avant-propos de l'édition de 1979, supra note 329, at 17-18.

333 Philippe Boucher, Christian Ranucci aurait été exécuté sur des prenves incertaines, LE MONDE, Sept. 9, 1978 (reviewing Perrault's book).

334 LE PULL-OVER ROUGE (Gaumont 1979).

335 Devant le groupe parlementaire d'étude sur la peine de mort Gilles Perrault évoque l'affaire Ranucci, LE MONDE, Nov. 17, 1978.

336 Id. (my translation).

337 PAUl CASSIA, RoBert BADINTER: Un JURISTE EN POLITIQUE 113 (2009).

338 Id., passim.
} 
headed toward abolition, he died in 1960 at forty-six years old in a car accident. Badinter would become the public face of the cause.

In this period, intellectuals, journalists, and politicians grew increasingly concerned about a climate of vengeful justice. Death threats fell on Badinter, whose Paris apartment was bombed in 1976. Undeterred, the following year Badinter convinced jurors to spare the life of Patrick Henry, who was widely reviled for murdering the aforementioned little boy. ${ }^{339}$ Badinter's summation arguments denounced the immorality of the death penalty: "Justice, is that the pain of the parents of Philippe Bertrand, combined with the pain of Patrick Henry's parents, if you let him be guillotined? The death of a twenty-three year-old man to respond to the death of a seven-year-old child, that is not justice." 340 Badinter warned the jurors that no appellate reversal or executive clemency would follow-they would be responsible for Henry's death:

You can kill him or not. If you vote death, know he will be cut in half. Then time will pass. There will be other atrocious crimes, because they have always existed. And, then, one day, in ten years, in fifteen years, the death penalty will be abolished in France ... . And you will be alone with your vote. You will tell your children that you sentenced to death a child killer, and you will see their looks. ${ }^{341}$

French abolitionists kept pressing that any execution is inhumane. In 1979, Jean Bloch-Michel challenged Pierre Bouzat, the dean of the Rennes law school, who had defended the death penalty if used appropriately, such as without torturous acts. Bloch-Michel was unconvinced: "Torture is unacceptable. The death penalty is acceptable. Why?"342

Certain French abolitionists underlined practical problems surrounding the penalty's application. This led to a vigorous reaction from Jean Laplanche, a writer and psychanalyst, who published a widely-publicized article deeming France's death-penalty debate “dehumanizing” given its utilitarian dimensions. In Laplanche's view, society was weighing the worth of offenders and victims to see which murderers deserved to die_-instead of valuing every person's life. ${ }^{343}$

339 LE NAOUR, supra note 67, at 305-07, 309-13. See supra note 330 and accompanying text. Badinter also received many insulting letters. L'angoisse de juger (Interview of Michel Foucault, Robert Badinter, and Jean Laplanche), May 30 1977, in FOUCAULT: DITS ET ÉCRITS, II 1976-1988 282, 291 (Daniel Defert \& François Ewald eds., 2001).

340 CASSIA, ROBERT BADINTER, supra note 337, at 118 (my translation).

${ }^{341} I d$. at 125 (my translation).

342 Bloch-Michel, La peine de mort en France, supra note 275, at 232 (emphasis in original) (my translation).

343 Jean Laplanche, Les voies de la déshumanité, LE NOUVEL OBSERVATEUR, Feb. 26, 1977, reprinted in JEAN LAPLANCHE, LA RÉVOLUTION COPERNICIENNE INACHEVÉE 59-66 (1997). See also L'angoisse de juger, supra note 
In a subsequent debate with Robert Badinter and Michel Foucault, Laplanche deplored a tacit agreement to only refer to utilitarian arguments. ${ }^{344}$ Badinter, by then a major public figure, responded that it was legitimate for him and fellow defense counsel to present utilitarian claims at trial if they were effective. He added that failing to rebut prosecutors' claims of deterrence would be a poor strategy. ${ }^{345}$ Badinter's answer reminds us how abolitionists, from France to America, had long found a polyvalent rhetoric the best strategy, even if they were morally opposed to executions per se.

Abolition finally arrived in 1981. The presidential election of the socialist François Mitterrand proved decisive in interrupting a series of conservative or centrist governments. ${ }^{346}$ Mitterrand had promised abolition if he were elected. ${ }^{347}$ Epitomizing a spectacular paradigm shift, he made Badinteran anti-death-penalty lawyer-the Minister of Justice.

In a solemn speech, Badinter appeared before the National Assembly to demand abolition on behalf of Mitterrand's government. ${ }^{348}$ After invoking past abolitionists, from French Revolutionaries to Victor Hugo, Jean Jaurès, and Albert Camus, Badinter signaled that France was a laggard in Western Europe in retaining capital punishment. ${ }^{349} \mathrm{He}$ sought to refute the arguments of retentionists, who interrupted him several times to trade barbs. Badinter notably emphasized executions' lack of deterrent value and the risk of executing innocents, citing the Ranucci case. ${ }^{350}$ Again evoking the transatlantic abolitionist dialogue, Badinter drew a comparison between the discriminatory application of capital punishment in America, where it heavily targeted black people, and in France, where immigrants and Muslims disproportionately stood among the executed. ${ }^{351}$

Moreover, Badinter's polyvalent discourse stressed the death penalty's fundamental inhumanity, stating four times that abolition is a "moral choice." 352 He urged legislators to "refuse a justice that kills," a "justice of angst and death," an "anti-justice" that would be "fear triumphing over reason and humanity." ${ }^{353}$ Executions are characteristic of "dictatorships," where "contempt for human

339, at 282 (mentioning reactions to Laplanche's article).

${ }^{344}$ L'angoisse de juger, supra note 339, at 282.

${ }^{345} I d$. at 282-86.

346 ZIMRING, supra note 21, at 22.

${ }^{347}$ LE NAOUR, supra note 67, at 343.

348 Robert Badinter, Speech at the National Assembly, Sept. 17, 1981, in ROBERT BADINTER, L'ABOLITION DE LA PEINE DE MORT 119 (2007).

${ }^{349}$ Id. at $120-21$.

350 See generally id. at 119-55. On Ranucci see supra note 332 and accompanying text.

351 Badinter, supra note 348, at 146-47.

${ }^{352} I d$. at $131,137,142,150$.

${ }^{353}$ Id. at 149. 
rights" reigns. ${ }^{354}$ Few people possessed as much credibility to draw this parallel between authoritarianism and state killing. Under the Nazi occupation of France, Badinter's father and other family members were deported to death camps pursuant to anti-Semitic laws. ${ }^{355}$

A few weeks after Badinter's speech, Parliament voted overwhelmingly for abolition. This was partly because Mitterrand's Socialist Party held numerous seats, but also because of a wider evolution. Tellingly, legislators who voted for abolition encompassed certain conservative leaders, including Jacques Chirac, who was elected President in 1995, and François Fillon, who became Prime Minister in $2007 .{ }^{356}$ This paradigm shift did not occur suddenly. It was the fruit of a gradual evolution that can be traced at least to the Renaissance and Enlightenment. France was but one stage in a wider historical evolution that would culminate in Europe officially recognizing that the death penalty is inherently inhumane.

\section{The Modern Transatlantic Divergence: "A Human Rights Violation" VERSUS “A BROKEN SYSTEM”}

Until the last decades of the twentieth century, abolitionism in America and France, if not the rest of Europe, converged more than it diverged. Since the Enlightenment abolitionists had polyvalently marshaled humanistic and practical objections to the death penalty. Yet social shifts in modern America led humanistic approaches to decline under a dramatically harsher social climate. Executions resurged in the 1980s after the Supreme Court emphatically reauthorized capital punishment in Gregg v. Georgia (1976), after technically abolishing it in Furman v. Georgia (1972). In these cases, the only Justices who focused primarily on the death penalty's inhumanity and substantive cruelty were William Brennan and Thurgood Marshall, both of whom voted for categorical abolition. The remaining Justices concentrated on administrative, procedural, and utilitarian issues. ${ }^{357}$ This fostered a path dependence under which practical issues would dominate the U.S. death penalty debate

\footnotetext{
354 Id. at $138-39$.

355 CASSIA, ROBERT BADINTER, supra note 337, at 9, 12.

356 LE NAOUR, supra note 67, at 281, 297, 302, 343, 349. The National Assembly's vote was 363-117, and the Senate's 161-126. Id. at 348, 351. See also Loi 81-908 du 9 octobre 1981 portant abolition de la peine de mort, JOURNAL OFFICIEL DE LA RÉPUBLIQUE FRANÇAISE, Oct. 10, 1981 (law abolishing death penalty).

357 Gregg v. Georgia, 428 U.S. 153 (1976) (plurality opinion); Furman v. Georgia, 408 U.S. 238 (1972) (per curiam). See generally BANNER, supra note 60, at ch. 9, 10.
} 
in subsequent decades, ${ }^{358}$ eclipsing humanistic concerns. ${ }^{359}$ Moreover, the rise of mass incarceration in this epoch essentially signified mercy for no one. ${ }^{360}$ In capital cases and beyond, humanistic principles have scant influence in modern America, which now has the highest incarceration rate worldwide. ${ }^{361}$ Under these circumstances, U.S. abolitionists plausibly found humanistic arguments less promising. Another possibility is that the normative shift toward draconian punishments affected social reformers, including in the "progressive" camp, by leading them to become less humanistic in outlook. This may have resulted in the emergence of the non-humanist abolitionist, if not the anti-humanist one who morally supports the death penalty but deems it unworkable.

Again, this trend is relative, not absolute. ${ }^{362}$ Certain American abolitionists suggest that executions are fundamentally wrong. In doing so, they employ a polyvalent rhetoric blending humanistic and practical reasons. ${ }^{363}$ Still, the modern emphasis on practicality is remarkable by U.S. historical standards and international ones.

By contrast, as abolitionism triumphed in Europe categorical humanistic objections came to trump practical ones. This led to the divergence that Franklin Zimring brilliantly captured, ${ }^{364}$ which is best understood as the present point of a long-term evolution whose earlier periods have been overlooked. The shift in Europe is not that human rights norms suddenly emerged around the 1970s, as Zimring and Samuel Moyn argue, ${ }^{365}$ but that they became the official basis for abolition. ${ }^{366}$ This was the fruit of a gradual normative evolution partly precipitated by generations of abolitionists denouncing the inhumanity, cruelty, barbarity or immorality of executions. In 1983, the Council of Europe issued an optional protocol abolishing the death penalty except in wartime. ${ }^{367}$ A protocol abolishing it in all circumstances followed in $2002 .{ }^{368}$ The second treaty is more explicit about its

\footnotetext{
358 STEIKER \& STEIKER, COURTING DEATH, supra note 8, at 50; Weisberg, supra note 250, at 315.

359 Steiker \& Steiker, Cost and Capital Punishment, supra note 58, at 151-55.

360 See generally Jouet, supra note 25, at 713-23.

361 WORLD PRISON BRIEF, supra note 13.

362 See GARRETT, supra note 10, at ch. 10 (discussing mercy's role in capital cases and beyond).

363 See supra note 7.

364 See supra note 32 and accompanying paragraph.

365 See supra Section I.

366 Another issue is beyond this Article's scope: whether European abolitionism reflects the greater influence of elites and counter-majoritarian mechanisms. See HAMMEL, supra note 35, passim.

367 Protocol No. 6 to the Convention for the Protection of Human Rights and Fundamental Freedoms Concerning the Abolition of the Death Penalty, Apr. 28, 1983, Europ. T.S. No. 114 (ratified by all member states except Russia).

368 Protocol No. 13 to the Convention for the Protection of Human Rights and Fundamental Freedoms Concerning the Abolition of the Death Penalty in All Circumstances, May 3, 2002, Europ. T.S. No. 183 (ratified by all member states except Armenia, Azerbaijan, and Russia, which are abolitionist in practice).
} 
humanistic rationale, as its preamble underlines "the right to life" and "the inherent dignity of all human beings." 369 The European Union has taken an identical position. ${ }^{370}$

A premise behind human rights rooted in dignity is that they are inalienable. ${ }^{371}$ One cannot forfeit them by committing a crime or for any other reason. The focus is not on the worth of an individual offender's life but on the worth of all human beings at an abstract level. ${ }^{372}$ Human dignity has evolved toward universality and is not based on individual merit. ${ }^{373}$ European law thus essentially recognizes respect for human rights and dignity as a duty imposed on government. Irrespective of whether a murderer is despicable, the government should never lower itself to their level by killing an incapacitated person. Conversely, American law holds that people can forfeit their life by committing murder and discounting their duty toward others. The value of their life is tied to individual merit. ${ }^{374}$ While America recognizes certain inalienable rights, ${ }^{375}$ Europe is more inclined toward this approach, helping shape distinct forms of abolitionism.

To his credit, the divergence in framing that Zimring identified has strengthened since his book's publication in 2003. In Al-Saadoon (2010), the European Court of Human Rights (ECHR) held that the death penalty inherently violates the right to life and right not to face inhuman or degrading punishments under the European Convention on Human Rights. Hence, it categorically barred extraditing anyone who might be executed. ${ }^{376}$ Previously, in Soering (1989), the ECHR had focused on administrative problems in forbidding the extradition of a detainee who could have been executed in America. Sidestepping the inhumanity of the death penalty itself, Soering found extended delays in executions a form of mental torture since prisoners live for years on death row under threat of being killed. ${ }^{377}$ Now Europe has essentially abandoned Soering in favor of an unconditional humanistic abolitionism.

Soering nonetheless was the chief European source that U.S. Supreme Court Justices Stephen Breyer and Ruth Bader Ginsburg cited in their landmark 2015 dissent urging another test case to

\footnotetext{
$369 \mathrm{Id}$.

370 See, e.g., Council of Europe \& European UniOn, Joint Declaration on the Death Penalty, supra note 5.

371 See generally Olivier DE FrOUVILlE, L'INTANGIBILITÉ DES DROITS DE L'HOMME EN DROIT INTERNATIONAL 117-25 (2004).

372 Kleinfeld, supra note 78, at 984-96.

373 CASSIA, DigniTÉ(S), supra note 6, at 24-27, 51-52.

374 Kleinfeld, supra note 78, at 942, 991-96.

375 See, e.g., Roper v. Simmons, 543 U.S. 551 (2005) (holding that executing a juvenile is categorically "cruel and unusual").

376 Al-Saadoon, Eur. Ct. H.R., supra note 6, ๆף 115-23.

377 Soering v. United Kingdom, App. No. 14038/88 Eur. Ct. H.R. (1989).
} 
Draft. Final, updated version forthcoming in American Journal of Comparative Law.

abolish capital punishment. ${ }^{378}$ Breyer and Ginsburg made no reference to human rights or dignity in their lengthy opinion, even when indicating that Europe no longer executes anyone. ${ }^{379}$ Despite listing every conceivable practical objection to the death penalty, they never suggest that executions are intrinsically cruel or inhumane. ${ }^{380}$ Republished as a book, ${ }^{381}$ the dissent was effectively a manifesto of modern American abolitionism.

In 2020, Breyer and Ginsburg reiterated their position as they dissented against the federal government's first execution in seventeen years. Their stance again focused solely on problems surrounding the death penalty's implementation. ${ }^{382}$

"A broken system" has become the quintessential American abolitionist argument. It is exclusively practical: the term "broken" implies that the death penalty "does not work." Popularized by studies documenting the colossal reversible error rate in U.S. capital cases, ${ }^{383}$ the phrase is ubiquitous nowadays. ${ }^{384}$ It signifies that the system is rife with due process violations, abysmal courtappointed lawyers, exonerations of innocents, endemic racial and class bias, and exorbitant financial costs. Evidence of these problems is damning, prompting numerous U.S. experts to disavow capital punishment. ${ }^{385}$

Yet rhetoric-wise the "broken system" paradigm may prove too much by conceding two points. First, the death penalty's inhumanity, cruelty or immorality is irrelevant. This may be the case for empiricists who assess reversal data and other quantitative matters. But the modern abolitionist movement generally concedes the point, too. In fact, the "broken system" expression suggests that killing prisoners would be appropriate if the system were not broken. Second, the expression implies

${ }^{378}$ Glossip v. Gross, 135 S. Ct. 2726, 2767 (2015) (Breyer, J., dissenting) (citing Soering, at p. 439).

${ }^{379} I d$. at 2776.

380 See supra note 2 and accompanying text.

381 BREYER, supra note 3.

382 Barr v. Lee, No. 20A8, slip. op. at 2-3 (U.S. July 14, 2020) (per curiam) (Breyer, J., dissenting).

383 James S. Liebman et al., A Broken System: The Persistent Patterns of Reversals of Death Sentences in the United States, 1 J. Of Empirical Legal Stud. 209 (2004); James S. Liebman et al., A Broken System, Part II: Why There Is So Much Error in Capital Cases, and What Can Be Done About It (2002), http://www2.law.columbia.edu.proxy3.library.mcgill.ca/brokensystem2/; James S. Liebman, Jeffrey Fagan \& Valerie West, A Broken System: Error Rates in Capital Cases, 1973-1995 (2000), https://scholarship.law.columbia.edu/faculty_scholarship/1219/.

384 See, e.g., Adam Liptak, Shapers of Death Penalty Give Up on Their Work, N.Y. TimES, Jan. 5, 2010 ("What the [American Law Institute] was saying is that the capital justice system in the United States is irretrievably broken."); $8^{\text {тн }}$ Amend. Project, The Death Penalty Is Broken Beyond Repair, http://www.8thamendment.org/ (last visited June 27, 2020).

385 See generally Steiker \& Steiker, No More Tinkering, supra note 9, passim; Sherod Thaxton, Disciplining Death: Assessing and Ameliorating Arbitrariness in Capital Charging, 49 ARIZ. ST. L.J. 137, 140-46 (2017). 
that the death penalty worked well before being "broken." If so, why would it be categorically unrepairable? The death penalty has actually never been proven to be a deterrent, has always risked executing innocents, and has always applied arbitrarily, discriminatorily or disproportionately to vulnerable groups. Miscarriages of justice were not born with modernity. ${ }^{386}$ By the standards that U.S. abolitionists stress today, the death penalty has never "worked" in America or Europe. It is therefore not "broken."

Whether practical or humanistic claims are more effective in winning abolition is beyond the scope of this Article. We have instead examined processes of convergence and divergence in abolitionism since the Enlightenment. If history is a guide, it suggests that American abolitionists can employ a polyvalent rhetoric encompassing both categories of arguments, which are not inherently incompatible.

\section{CONCLUSION}

To borrow a precept from Montaigne, "a general duty of humanity" 387 emerged in the Renaissance before progressing in the Enlightenment and onward. Following in Beccaria's footsteps, generations of abolitionists in Europe and America recurrently denounced the cruelty of capital punishment in reasoning analogous to modern conceptions of human rights and dignity. This evidence bolsters Durkheim's theory that an expanding norm of "human dignity," tied to the development of liberal democracy, gradually mildened punishments. ${ }^{388}$

This Article has documented how the "moral" or "political" objection to executions, which is at the heart of human rights abolitionism nowadays, ${ }^{389}$ can be found in the positions of generations of abolitionists in both Europe and America. The overwhelming focus on administrative, procedural, and utilitarian objections to capital punishment in modern America has obscured how past U.S. abolitionists commonly employed a humanistic rhetoric, just like their European counterparts. History cautions against cultural essentialism assuming that such sensibilities are foreign to America. It was in

\footnotetext{
386 See generally BANNER, supra note 60, passim; LE NAOUR, supra note 67, passim.

387 MONTAIGNE, supra note 97, at 385.

388 Durkheim, supra note 26, at 88.

389 ZIMRING, supra note 21, at 25.
} 
modern times that a harsher America began focusing overwhelmingly on practical questions, whereas human rights became the official ground for abolition in Europe.

Today, European authorities do not merely refuse to facilitate executions by extraditing detainees. ${ }^{390}$ Following a campaign by Reprieve, a British human rights group, Europe barred the export of drugs used for lethal injection in America. ${ }^{391}$ This helped precipitate the U.S. Supreme Court case in which Justices Breyer and Ginsburg issued their call for abolition. ${ }^{392}$ In fact, Europe aspires to spearhead global abolition. While such an international legal and diplomatic campaign appears unprecedented, ${ }^{393}$ its moral foundation evokes the positions of abolitionists on both sides of the Atlantic since the Enlightenment, in the image of the petition that Henry David Thoreau and his peers signed in 1849: "[An execution is] a crime in which we would under no circumstances participate, which we would prevent if possible and in the guilt of which we will not by the seeming assent of silence, suffer ourselves to be implicated." ${ }^{\prime 394}$

\footnotetext{
390 See supra note 376 and accompanying text.

391 European Commission, Commission Extends Control Over Goods Used for Capital Punishment or Torture (Dec. 20, 2011), https://ec.europa.eu/commission/presscorner/detail/en/IP_11_1578; REPRIEVE, Europe Blocks Export of Lethal Injection Drugs (Dec. 20, https://reprieve.org.uk/press/2011_12_20_european_commission_lethal_injections/.

392 Glossip v. Gross, 135 S. Ct. 2726, 2733 (2015).

393 ZIMRING, supra note 21, at 26-41.

394 Wheeler, supra note 204, at 1.
} 